\title{
A HAMBURG CHILDHOOD: THE EARLY LIFE OF HERBERT BERNSTEIN
}

\author{
PAUL H. HAAGEN*
}

On the evening of April 19, 2001, Herbert Bernstein's wife, Waltraud, decided to watch Schindler's List, and she invited Herbert to join her. That evening, her mind was very much on the past, because the following day would be the anniversary of Hitler's birthday. ${ }^{1}$ Herbert told her that he could not, that he had too much work to do. The following day he had to teach his final two classes of the term, and he still had to do last minute revisions on the manuscript of the book he was writing with Joseph Lookofsky, the second edition of Understanding the CISG in Europe. As the evening wore on, however, the lure of the movie and of the chance to spend the evening with Waltraud proved too strong and he left his study to join her. The movie, which is powerful enough for audiences with little connection to that time and place, ${ }^{2}$ deeply moved Herbert, who had strong ties of memory with both. He slept very fitfully that night. ${ }^{3}$

No one who encountered him the next morning would have had any sense of the burden of that past on him. I suspect that none of his colleagues were aware that it was Hitler's birthday. If there were those who were, theirs would have been an intellectual or political awareness, not a personal one. Unlike Herbert, they had not lived

Copyright $@ 2003$ by Paul H. Haagen.

* Professor of Law, Duke University. I would like to thank Waltraud Bernstein, who gave me invaluable assistance with this essay, Professor Deborah DeMott who urged me to write it, and Professor Ralf Michaels for his bibliographic assistance. The Dean and Faculty of Law at the Johannes Kepler Universität in Linz, Austria, where I was Visiting Professor, provided the facilities and quiet to enable me to bring it to completion.

1. Adolf Hitler was born in Braunau-am-Inn in Austria on April 20, 1889. IAN KERSHAW, HitLeR, 1889-1936: Hubris 10-11 (1999) [hereinafter KERSHAw, HubRIS]. After Hitler came to power, it became the most important holiday in the Nazi calendar, and an opportunity to display "the might and power of the Third Reich." Id. at 184-85 (describing the extraordinarily elaborate displays orchestrated by Goebbels in connection with Hitler's fiftieth birthday in 1939).

2. See, e.g., Tim Dirks, Review of Schindler's List, The Greatest Films, at http:// www.filmsite.org/schi.html (last visited Oct. 4, 2002).

3. Except where otherwise noted, the sources of personal information about Herbert Bernstein are either from him directly or from members of his immediate family. 
through those celebrations. Herbert was not likely to have said anything about it. He spoke to me that morning about the end of the term, and the imminent sending-off of his manuscript. He told me that he was looking forward to being with me and my family in Hong Kong that summer. He joked and exchanged pleasantries with the staff and other colleagues. It was not his habit to burden others with the burden of his past. ${ }^{4}$

My personal awareness of his early life came relatively late in our fifteen-year relationship. I knew that Herbert Bernstein was a man of great erudition and deep humanity. He was funny, irreverent, and insatiably curious about nearly everything. As to the few topics that did not interest him, he managed to show considerable interest in the question of why he was not interested. Herbert carried himself with the easy intellectual grace and sophistication of someone who had been to the academic manor born. I assumed that he had been. In recent years, I discovered in bits and pieces that the reality of his upbringing was very different. His early life was one characterized by deprivation and disruption that would have crushed many and left those uncrushed cynical, embittered, and suspicious. These experiences seem to have produced the opposite effect in him. They deepened his tolerance for others and his commitment to make those parts of the world that he touched more decent and humane.

When Herbert had a massive heart attack and died in the Law School shortly before noon on April 20, 2001, the Dean asked me to write a short piece about him on behalf of the Law School for release to the press. What I wrote concentrated heavily on what he had told me about the experiences of his early life. ${ }^{5}$ My remarks at his memorial service several days later were even more directed at those expe-

4. I suspect that some of his reluctance to speak about his experiences during the Third Reich reflected the uneasiness of a survivor. He was keenly aware that others, including others in his own family, had suffered more than he had and had not survived. This awareness comes through strongly in the unfinished essay that he was working on at the time of his death, reflecting on his experiences with the Nuremberg Laws. See Herbert L. Bernstein, Reflections on the Nuremberg Laws, (incomplete and unpublished manuscript, on file with the Duke Environmental Law and Policy Forum) [hereinafter Bernstein, Reflections]. Herbert began working on this project several years before his death. He regarded it as an important coming to grips with his experience of Nazi Germany, but clearly found it difficult to work on and did not bring it to completion. I am grateful to his widow Waltraud Bernstein for allowing me access to the manuscript.

5. Press Release, Duke University School of Law, Duke Law Professor Herbert Bernstein Dies at Age 71 (April 20, 2001) available at http://www.dukenews.duke.edu/Law/bernstei.htm (essentially the same press release the author prepared). 
riences. ${ }^{6}$ In putting together this volume, Professor Deborah DeMott asked me to expand those remarks into a paper. This essay is the result. I have attempted to stitch together various stories that Herbert had told me over the course of our friendship ${ }^{7}$ and to put them into some sort of historical context. It is a narrative of his boyhood in Hamburg during the worst years in that city's history. It is a remarkable tale of survival, and of the struggle of one boy to be allowed to create his own identity.

\section{HAMBURG}

Herbert Bernstein was born in Hamburg, Germany on January 12, 1930. It was not the most auspicious of times and places to make an appearance in the world. Hamburg is a city of great beauty, with a long and proud history. But in January, it is cold and grey. The temperature hovers around freezing, and the damp that rolls in off the North Atlantic hangs stubbornly over the city. ${ }^{8}$ In January 1930, the cold greyness of the weather mirrored a much more ominous cold greyness in the economic and political situation of Germany in general and of Hamburg in particular. For those inclined to read the heavens, there was something especially troublesome in the fact that the god of the underworld made his presence known to man only a month after Herbert's birth. ${ }^{9}$

6. Paul H. Haagen, Remarks at the Duke University School of Law Memorial Service for Herbert Bernstein (April 25, 2001), available at http://www.law.duke.edu/fac/bernstein/haagen. html.

7. Personal memories of events that took place more than a half century ago are often very unreliable as historical sources. Events get conflated and stories embellished. So many of the documents relating directly to the events in Herbert Bernstein's life have fallen victim to the chaos he survived, or have otherwise been inaccessible to me in doing the research for this paper, that it is impossible to document his stories with precision. That said, I have been struck by the fact that nothing that Herbert Bernstein told me has turned out to be implausible or in conflict with any of the general histories of the period. It appears to me that in his memories of his own life, he maintained the same fidelity to truth and accuracy that he displayed in his scholarship.

8. For an account of the experience of the cold of a Hamburg winter, see MATHILDE WOLFF-MÖNCKEBERG, ON THE OTHER SIDE, TO MY CHILDREN: FROM GERMANY 1940-1945 at 30-35 (Ruth Evans ed. and trans., Mayflower Books) (1979).

9. Clyde Tombaugh, working at the Lowell Observatory in Flagstaff, Arizona, discovered the ninth planet, on February 18, 1930. The existence of the planet, which was then named after the god of the underworld, Pluto, had been hypothesized for years. See Clyde W. Tombaugh, The Struggles to Find the Ninth Planet, NASA/JPL Outer Planets/Solar Probe Project, at http://www.jpl.nasa.gov/ice_fire//9thplant.htm(last modified Dec. 5, 2000); Clyde W. Tombaugh, The Discovery of a Solar System Body Apparently Trans-Neptunian, Lowell Observatory, Observation Circular, available at http://www.jpl.nasa.gov/ice_fire/s_dscvry.jpg. 
Hamburg had been, for much of its history, a prosperous Hansastadt, proud of its independence. ${ }^{10}$ In the middle of the nineteenth century, it began to take on a very different form and role in the world, the change driven in large part by trade with the English speaking world. ${ }^{11}$ As late as 1850 , Hamburg was still relatively small, with only fifty thousand inhabitants. By the end of the century, the old Hansastadt had been transformed into a thriving international entrepôt of one million inhabitants. By the first decade of the twentieth century, it had become the second largest city in the Reich, the largest port on the Continent of Europe, and Germany's second largest industrial center. ${ }^{12}$ Hamburg continued to grow following the First World War, despite repeated economic crises and political upheaval. Its population reached 1,236,000 in the year Herbert was born, and then increased an additional forty-one per cent over the first nine years of his life. ${ }^{13}$

In the context of that time and place, Hamburg was a liberal and progressive city. ${ }^{14}$ It was a place in which $\mathrm{Jews}^{15}$ found a large meas-

10. Hamburg lost a significant part of that independence in 1871 , when it was absorbed in the German Reich. Weltmachttaumel und Wahlrechtskämpfe [World Power Frenzy and the Struggle for Voting Rights], Museum für Hamburgische Geschichte [Hamburg Museum], at http://www.hamburgmuseum.de/d/htm_d/textversion/20jhd-1-01.html (last visited Oct. 4, 2002). Today, it is the second smallest of the sixteen German Länder, and its pride in its past is expressed in its official name, The Free and Hanseatic City (Freie und Hansestadt) of Hamburg. Hamburg in a Nutshell, at http://www.hamburg.de/fhh/international/englisch/hamburg_kurz.htm (last visited Oct. 4, 2002). See WOLFF-MÖNCKEBERG, supra note 8, at 16.

11. Some of this growth was achieved by incorporating surrounding communities. See Hamburg City History, at http://www.hamburg.de/fhh/international/englisch/geschichte_ hamburgs_2.htm (last visited Oct. 4, 2002). It was one of the most important ports of embarkation for European emigrants to North America and Australia. Between 1850 and 1934, five million of such emigrants passed through the port of Hamburg. Hamburg and the English Speaking World, at http://www.hamburg.de/fhh/international/englisch/index.htm (last visited Oct. 4, 2002).

12. Groß-Hamburg [Greater Hamburg], Museum für Hamburgische Geschichte [Hamburg Museum], at http://www.hamburgmuseum.de/d/htm_d/textversion/20jhd-1-08.html (last visited Oct. 4, 2002). It was either the third or fourth largest port in the world. THE UNITED STATES Strategic Bombing Survey, Hamburg Field RePort 2 (1947) [hereinafter Hamburg FIELD REPORT]. But $c f$. MARTIN CAIDIN, THE Night HAMBURG DiED 13 (1966).

13. Welthafen und Wirtschaftsmetropole [World Port and Commercial Metropolis], Museum für Hamburgische Geschichte [Hamburg Museum], at http://www.hamburgmuseum.de/d/htm_d/ textversion/20jhd-1-04.html (last visited Oct. 4, 2002).

14. See KERSHAW, HUBRIS, supra note 1, at 287 (describing Hamburg as Germany's most liberal city). When Hitler came to address the Hamburger Nationalklub on February 28, 1926, he recognized that anti-Semitic race baiting would be counter-productive with his Hamburg audience. In his two-hour speech, he did not make a single reference to Jews. Id. at 286. See also WOLFF-MÖNCKEBERG, supra note 8, at 16.

15. In trying to conduct a census of the number of Jews in Hamburg, the leaders of the Jewish community faced the awkward problem of whom to include. This proved to be almost as difficult a determination for them to make in determining who should be included in their 
ure of toleration and acceptance. Jews found so much acceptance as individuals, and had such easy social interaction with the larger society of Hamburg, in fact, that the leaders of the Jewish community feared that its members would lose their distinct identity. In response, they developed the "Hamburg system," which attempted to preserve Jewish rituals and practices by reaching out to non-religious Jews. $^{16}$ Their problem of maintaining Jewish identity was not, however, merely a matter of meeting the challenge of secularization and acculturation. They also had to contend with very high rates of marriage outside the community. About half of all Jews in Hamburg who married between 1925 and 1933 married non-Jews. ${ }^{17}$ The response of the Jewish leaders of Hamburg to this development was more divided. The Hamburg Temple Association attempted to embrace the non-Jewish spouse and worked to integrate him or her into the Jewish community. The Hamburg Synagogue Association tried to discourage the practice of marrying outside the community by refusing membership to non-Jewish spouses. ${ }^{18}$

The city's liberal and progressive traditions were seriously challenged in the fifteen years before Herbert's birth by economic and political turmoil that created serious hardship for its inhabitants. Ultimately, they failed the challenge. The British naval blockade during the First World War effectively closed the port to international traffic and produced massive shortages of food and fuel. By 1917, rations provided for only a thousand calories a day, half of the average calorie intake before the war. In the country as a whole, it is estimated that three quarters of a million people died of malnutrition. ${ }^{19}$ Privation was then followed by military defeat, and military defeat by the

community, as it would in the much more insidious decisions made by the Nazis about whom to exclude from theirs. The Jewish community's census in 1926 came up with a figure of just under 21,000 , a number that did not include the acculturated, non-practicing Jews, whom the Nazis later would add in their broader Rassejuden definition. Only about half of those included in the Jewish community survey had been born in Hamburg. Dr. Ina S. Lorenz, The DeutschIsraelitische Gemeinde/German-Israelite Community in the Weimar Republic, in A HISTORY OF JEWS IN HAMBURG (Struan Robertson, trans.) at http://rrz.unihamburg.de/rz3a035/ jew_history3.html (last modified Oct. 2, 2000).

16. See id. (referring to the practice as "consciously accept[ing] insidious acculturation").

17. Id. This calculation obviously involves all of the definitional problems associated with determining who counted as a Jew.

18. Id. Herbert's father was a secular, not a religious person. Whether this debate was of interest at the time to him and to his German wife is not at all clear.

19. KERSHAw, HUBRIS, supra note 1, at 99. On conditions in Hamburg during the war, see Lebensverhältnisse im Kaiserreich [Conditions of Life in the Empire], Museum für Hamburgische Geschichte [Hamburg Museum], at http://www.hamburgmuseum.de/d/htm_d/ textversion/20jhd-1-02.html (last visited Oct. 4, 2002). 
imposition of the punitive terms of the Treaty of Versailles. Those terms included, among other things, the confiscation of virtually the entire merchant fleet of Hamburg. ${ }^{20}$ The shipping industry was the center of Hamburg's economy. ${ }^{21}$ Crippling it crippled the whole economy. The confiscation was followed by the devastating effects of hyperinflation during $1922-1923 .^{22}$

Patrician inhabitants of Hamburg remained confident in the strength and uniqueness of their traditions, and dismissive of radicals like the "common little house painter from Austria." ${ }^{23}$ But the repeated upheavals of the period 1915 to 1930 took their toll and created conditions in which complacent confidence proved misplaced. The city's prosperity had become, for most of its population, only a dim memory, and its vaunted independence was fading under the impact of economic trends that it could not control. As Hamburg's economy slipped into Depression in 1929-30, the formerly unresponsive ground of Hamburg became increasingly fertile territory for political extremists. ${ }^{24}$ The Nazis placed second in the city elections in 1931, barely behind the first-place Social Democrats. ${ }^{25}$ They did even better the following year, getting 31.2 per cent of the Hamburg vote in the April national elections and finishing first.

Immediately before that election, Hitler flew into Hamburg to address a cheering crowd of more than 120,000 on April 23, 1932. ${ }^{26}$ Luise Solmitz, a Hamburg schoolteacher, recorded her thoughts after witnessing the event:

How many look to him in touching faith as the helper, saviour, the redeemer from great distress. To him, who rescues the Prussian prince, the scholar, the clergyman, the peasant, the worker, the unemployed out of the party into the people. ${ }^{27}$

Herbert Bernstein was two years old.

20. The Peace Treaty of Versailles, June 28, 1919, Part VIII: Reparations, Annex III, sections 1-9, available at $\mathrm{http}: / / \mathrm{www} . l i b . b y u . e d u / \sim \mathrm{rdh} / \mathrm{wwi} / \mathrm{versa} 7 . \mathrm{html}$.

21. There were ninety-seven miles of docks to serve the vessels. HAMBURG FIELD REPORT, supra note 12, at 2. At the start of the war, there were more than 3,000 industrial establishments and 5,000 commercial firms, the vast majority of which were connected directly or indirectly to the shipping industry.

22. See Bernd Widdig, Culture ANd Inflation in Weimar Germany (2001).

23. See WOLFF-MÖNCKEBERG, supra note 8 , at 16.

24. On the very active response of the Hamburg Jewish community to the threat posed by the Nazi party, see Lorenz, supra note 15.

25. Kershaw, HUBRIS, supra note 1 , at 355 .

26. Id. at 364-65.

27. Id. at 364 . 


\section{THE NAZIS COME TO POWER}

Adolf Hitler became Chancellor of Germany on January 30, 1933. There was little doubt that his appointment was going to be bad for German Jews. His, and his Party's, hostility to Jews was open and the rhetoric that he directed against them violent. The only questions were how bad, for how long, and who in the Jewish community would be affected the most. There was always the hope that once in office Hitler would be more responsible than he had been as an outsider agitating to get in, or that he would be outmaneuvered by more experienced politicians in less radical parties. There was always the hope that the next election would produce different results, and that the Nazis would be turned out of government. The next three months went a long way toward extinguishing any realistic grounds for hope.

Following the Reichstag fire on February 27, the Party moved to consolidate its power in a swift and brutal fashion. ${ }^{28}$ Hitler persuaded President Hindenburg to sign an emergency decree on February 28, 1933 that suspended most of the guarantees of personal freedom contained in the German Constitution in order to permit the government to defend itself against "communist acts of violence endangering the state." 29 The Nazis then proceeded to arrest and imprison tens of thousands of their political opponents in a reign of terror that the peasant leader Georg Heim called worse than that of the Communists. ${ }^{30}$ In the state governments that the Nazis did not control directly, they pressured local officials to put Nazis in control of the police, and purge those officers whom they regarded as unreliable. ${ }^{31}$ The government in Hamburg readily complied with their demands. ${ }^{32}$ With much of the leadership of the Left under arrest, Hitler then cajoled and bullied the Reichstag into passing the notorious Enabling Act - "Law for the Removal of the Distress of People and Reich" - in

28. Id. at $456-63$.

29. Verordnung des Reichspräsident zum Schutz von Volk und Staat [Decree of the Reich's President on the Protection of the People and the State] v.28.2.1933 (RGB1.I S.83), available at http://www.documentarchiv.de/ns.html. Hindenburg acted pursuant to Article 48 of the German Constitution of August 11, 1919, which provided for the suspension of the Constitution in times of emergency. The decree was never withdrawn. See id.

30. KERSHAW, HUBRIS, supra note 1, at 463.

31. Id.

32. In Hamburg, ten per cent of commissioned police officers and two per cent of noncommissioned officers were dismissed for political reasons in 1933 as part of this purge. See Hamburg Police Battalions during the Second World War, in A HISTORY OF JEWS IN HAMBURG (Struan Robertson, trans.), at http://www.rrz.uni-hamburg.de/rz3a035/police101.html (last visited Oct. 4, 2002). 
the early evening of March 23, 1933..$^{33}$ Articles I and II of that Act gave authority to the Reich Cabinet to enact laws outside the normal provisions of the Constitution. By this act of legislation, the Nazis created the framework for the legal lawlessness that would characterize the regime. ${ }^{34}$

Nazi Party activists had long engaged in various forms of street level intimidation and thuggery with little direction from any central leadership and without regard for law of any type. When the Party assumed the reins of power, the levels of this violence, much of it directed at Jews, increased markedly. Radicals in the Party, dissatisfied with what could be accomplished by the acts of individual initiative, demanded a more coordinated approach in the form of a national boycott of Jewish-owned businesses. ${ }^{35}$ Jews outside of Germany, in response to the growing levels of violence and discrimination directed at Jews inside the Reich, attempted with some success to organize a boycott of German goods. ${ }^{36}$ Hitler reacted to this initiative, as he would to most opposition, by angrily striking back. In this case, Hitler sided with radicals in the Party against his Foreign Minister, Konstantin Neurath, and the President of the Reichsbank, Hjalmar Schacht, by agreeing to a one-day boycott of Jewish businesses to take place on April 1, 1933. The actual event, organized and enforced by the Sturmabteilung, ${ }^{37}$ was far from universally successful. Many non-Jews refused to be intimidated by the Brownshirts and defied the boycott. If largely unsuccessful in economic terms, it effectively

33. Gesetz zur Behebung der Not von Volk und Reich [Law for the Removal of the Distress of People and Reich], v.23.3.1933 (RGB1.I S.173), available at http://www.document archiv.de/ns.html.

34. The final act in this particularly macabre play was the Gesetz gegen die Neubildung von Parteien [Statute against the Formation of Parties], v.14.7.1933 (RGB1.I S. 479), available at http://www.documentarchiv.de/ns.html. Enacted on July 14, 1933, the statute declared in section one that the National Socialist Party was the sole political party in Germany, and in section two outlawed the formation of any new ones. Id. Since other parties ceased to exist, the Reichstag could be used to rubberstamp legislation if it seemed expedient to bother. It seldom did. Between 1933 and the beginning of the war in 1939, the Reichstag met only sixteen times and passed nine statutes. Operating under the special powers created under the Enabling Act, the Reich Cabinet promulgated approximately four thousand five hundred laws. Bernstein, Reflections, supra note 4, at 9.

35. Many of these attacks were carried out by the Fighting League of the Commercial Middle Class [Kampfbund des gewerblichen Mittelstands], who were able to give expression to their hatred of both Jews and the frequently Jewish owned department stores in a single act of violence. See KerSHAw, HUBRIS, supra note 1, at 471-72.

36. Id. at 472-73.

37. Dr. Ina S. Lorenz, The Deutsch-Israelitische Gemeinde/German-Israelite Community in the Weimar Republic, in A HISTORY OF JEWS IN HAMBURG (Struan Robertson, trans.), at http://www.rrz.uni-hamburg.de/rz3a035/jew_history4.html (last updated Oct. 2, 2000). 
traumatized many in the Jewish community, who realized how much and how quickly they had become strangers in their own country. ${ }^{38}$

The boycott was, moreover, just the beginning. It set the stage for a flurry of discriminatory statutes and decrees that both had an immediate harmful impact on Jews in Germany, and constituted a powerful demonstration of their vulnerability in the new Nazi state. The first piece of legislation, the "Law for the Reestablishment of a Professional Civil Service," was enacted on April 7, just six days after the boycott. ${ }^{39}$ This law, with certain exceptions for those who had served at the front in the First World War, or lost sons or fathers in that $w a r,{ }^{40}$ provided explicitly for the forced retirement of all "nonAryan" civil servants at all levels of government. ${ }^{41}$ In the context of the German State, "civil servants" was a very broad category of persons that included teachers and professors, as well as bureaucrats. But the reach of the legislation was even farther than that broad category might suggest. ${ }^{42}$ The statute itself explicitly authorized the national bank and rail system to adopt regulations to carry out the purposes of the law. Private employers who were not covered explicitly were strongly encouraged to take actions consistent with it, and some of the largest ones complied. ${ }^{43}$ On April 22, 1933, Jewish doctors were relegated to private practice, "deregistered" from the public health service. ${ }^{44}$ Three days later the Nazis enacted the Statute against Overcrowding of German Schools and Universities, limiting the number of non-Aryans permitted to attend school to the percentage of non-Aryans in German population. ${ }^{45}$ Jewish students in Ham-

38. KERSHAW, HUBRIS, supra note 1 , at 474.

39. Gesetz zur Wiederherstellung des Berufsbeamtums [Law for the Reestablishment of a Professional Civil Service], v.7.4.1933 (RGB1.I S.175), available at http://www.documentarchiv. de/ns.html.

40. The exceptions did not represent the views of the Nazi leadership. They had been inserted at the insistence of President Hindenburg. KERSHAW, HUBRIS, supra note 1, at 474.

41. Four days after the enactment of the law, the Nazis issued a clarifying order defining non-Aryan as including persons with at least one Jewish grandparent. See Bernstein, Reflections, supra note 4 , at 8 .

42. A year later, it was extended to reach members of the military. Id. at 18.

43. The "spirit of the law" was extended to private businesses and organizations as well through intense pressure from the Party. In April 1933, Gustav Krupp agreed to dismiss the Jewish employees of his vast commercial empire, and to remove Jews from all representative positions in industry and commerce organizations. KERSHAW, HUBRIS, supra note 1, at 448. According to Professor Lorenz, these dismissals were illegal under German law. Lorenz, supra note 37. It seems likely that Krupp, and others who gave into this pressure, were unconcerned that their actions might result in a finding of liability.

44. Lorenz, Die Deutsch-Israelitsche Gemeinde, supra note 37.

45. Gesetz gegen die Überfüllung deutscher Schulen und Hochschulen [Statute on the 
burg reported that individuals understood the enactment of this law to encourage and authorize various acts of discrimination and harassment directed at them. ${ }^{46}$

The Professional Civil Service Act did not contain any definition of "non-Aryan." This was a matter that the Nazis neither had worked out before they seized power, nor to which they had a uniform answer. The imprecision did not significantly affect the Aryan students, who now felt free to persecute their classmates, or Brownshirts engaged in street-level thuggery. Neither the local Nazi activists, nor most of the Party leadership, was overly concerned with the problem of false positives in these cases of harassment. ${ }^{47}$ The use of law to carry out the program of discrimination and economic isolation, however, required some sort of workable definition.

Four days after the passage of the legislation purging the civil service, the Nazis issued a clarifying decree defining anyone who had one Jewish grandparent as non-Aryan. ${ }^{48}$ This definition was then explicitly incorporated by reference in the "Statute against Overcrowding of German Schools and Universities." That statute contained a further elaboration to deal with the children of certain special classes of persons: the children of especially meritorious veterans and those whose parents had been married before the date of the statute. They were exempted from the category of non-Aryan if one parent and two grandparents were Aryan. ${ }^{49}$

Herbert's uncles, Kurt and Herbert, did not wait long to see whether this wave of hostility would pass and the earlier pattern of acceptance of Jews in Hamburg society would re-assert itself. Kurt

Overcrowding of German Schools and Universities], v.25.4.1933 (RGB1.I S. 225).

46. Lorenz, supra note 37. According to Hans Thielemann, soon after the passage of this legislation, anti-Semitic rhetoric began to "permeate" his grammar school and class in Berlin. Hans Thielemann, Memoirs of a Luftwaffe Nachtrichten Veteran, Feldgrau.com, at http:// www.feldgrau.com/interview4.html (last visited Oct. 4, 2002).

47. There were those like Hjalmar Schacht, who were opposed to street violence as dangerous, wasteful, and often counter-productive. Although generally inclined to want to keep the radicals in check, he did not demonstrate strong concern about who was affected by discriminatory legislation against Jews. KERSHAW, HUBRIS, supra note 1, at 473-74, 564-65.

48. Erste Verordnung zur Durchführung des Gesetzes zur Wiederherstellung des Berufsbeamtentums [First Regulation Implementing the Law for the Reestablishment of a Professional Civil Service] v.11.4.1933 (RGB1.I S.195).

49. Gesetz gegen die Überfüllung deutscher Schulen und Hochschulen [Statute on the Overcrowding of German Schools and Universities] v.25.4.1933 (RGB1.I S. 225), available at http://www.documentarchiv.de/ns.html. Herbert Bernstein, who had one Jewish grandparent, and whose parents were married before the promulgation of the law, was thus in the class of persons exempted from the restrictions imposed in the school law, even though he came within the definition of non-Aryan. 
emigrated to Brazil, Herbert to the United States. They were part of an initial wave of emigration from Hamburg that reduced the size of its Jewish community by a quarter within two years of the Nazis coming to power. ${ }^{50}$ How his uncle Herbert, the youngest of Leopold Bernstein's four children, managed to get one of the precious 25,957 quota spots allocated annually by the U.S. government to immigrants from the German Reich, ${ }^{51}$ Herbert did not know. They were extremely hard to obtain.

Leopold Bernstein did not want to leave. He wanted to stay. Although he was a Jew, ${ }^{52}$ he expected his military service in the First World War to give him some measure of protection, and there was reason in the initial wave of anti-Jewish legislation to believe that it might. Certain categories of veterans, such as those who had fought at the front in the First World War, and the family members of those who had lost fathers or sons in the war, were exempted from the forced retirement provisions of the civil service law, and their children were not included among those subject to the school quota law. His service in the Kaiser's army did not, however, protect him. He was dismissed from his job in 1933, because he was non-Aryan.

That act of discrimination was not, however, enough to convince him to leave the only world he knew, and the part of his family that still remained in Hamburg. He, like many others in the Hamburg Jewish community, hoped to figure out some way to accommodate himself to the new realities of life under the Nazis. ${ }^{53}$ When he finally decided in 1937 that there was no place for him in the Third Reich, he was unable to get one of the precious American immigration spots and join his son Herbert in the United States. He left instead to join Kurt in Brazil. After he had been unemployed for four years, he was too poor to bring any of his other relatives, not even his wife, along with him. ${ }^{54}$

50. Lorenz, supra note 37.

51. Willi Paul Adams, The German Americans, available at: http://www.lib.iupui.edu/ kade/adams/chap1.html. The quota established in 1929 was filled every year. It was not adjusted until after the war.

52. It has never been clear to me whether Leopold Bernstein maintained his connections with the Jewish community and with Jewish religious practice, and thus would have been considered a Jew by the Jewish community. There is no doubt that employing the "racial" definitions used by the Nazis, he was a Jew.

53. Ina Lorenz notes that after the initial shock of the events of April, 1933, many Jews in the Hamburg community experienced the period from 1933 to 1937 as one of comparative calm, and hoped that it would be possible to work out an accommodation with the Nazi regime. Lorenz, supra note 37.

54. His departure was part of a second wave of emigrations from Hamburg that followed 


\section{HERBERT'S PARENTS}

Although Herbert strongly identified himself with Hamburg, neither of his parents had been born there and both were relatively recent immigrants to the city. He believed that his ancestors were from the east, probably Poland, although neither he, nor apparently anyone else, was quite sure. His paternal grandfather, Leopold Bernstein, had been born in the fortress city of Spandau, which would later become part of Berlin. By 1905, Leopold had moved his family to the town of Cloetze in the Altmark region of Saxony Anhalt, where Herbert's father, Gerhard, was born. ${ }^{55}$ Sometime later he continued his westward trek, and moved his growing family to Hamburg. Herbert's maternal family, the Franzes, were from the port city of Kiel. ${ }^{56}$ Neither of his parents was educated. ${ }^{57}$

Even in the worst of times, some of the lucky members of society are able to insulate themselves, at least to some degree, from the impact of economic downturn and political change. ${ }^{58}$ Herbert's family could not. They had neither the wealth, nor connections to do so. Gerhard Bernstein was a working man. He labored, when he could get work, as a skilled pipefitter in Hamburg's shipping industry. $\mathrm{He}$ was not yet twenty-five when Herbert was born.

the enactment of the Nuremberg Laws in 1935, and further reduced the size of the Hamburg Jewish community to fewer than $40 \%$ of the number at the time Hitler was appointed Chancellor. The Jewish community in Hamburg attempted to aid those trying to emigrate, but the impact of economic discrimination and continued emigration reduced the resources of the community so substantially that such assistance was increasingly limited. By 1939, according to an official Nazi census, there were only 8,438 practicing Jews, 1,505 "Rassenjuden", and 4,187 "Mischlinge 2. Grade" left in the city. Id.

55. For background on the town of Cloetze, see Cloetze, Officially Recognized Holiday Resort [Stadt Klőtze, Staatlich anerkannte Erholungsort] at http://www.stadt-kloetze.de.

56. Kiel is a port on the western Baltic an hour north of Hamburg. Like Hamburg, Kiel had been part of the Hanseatic League, entering into the alliance in 1284. It was, however, far less successful in maintaining its independence. From the late eighteenth century, it was part of the Duchy of Schleswig-Holstein. The Kingdom of Denmark asserted control over it in the midnineteenth. Following the short Prusso-Danish War of 1864 and the even shorter PrussoAustrian War of 1866, it was ceded, along with the most of the rest of Schleswig-Holstein, to Prussia. Kiel was the site of the great German naval mutiny in November 1918.

57. According to Herbert, his mother's older sister had not had any advanced education. The family, therefore, regarded it as improper for the younger sister to have any.

58. For an account of the experience of the war years by a relatively privileged Hamburg family, see WOLFF-MÖNCKEBERG, supra note 8. The wife of the Professor of English Language and Literature at Hamburg University, and the daughter of a former Lord Mayor of Hamburg, "Tilli" expressed great concern in her diary at the news that Germany had invaded Holland and Belgium. In an effort to cheer herself up, she attended a performance of Johann Strauss's operetta Wiener Blut, which she noted was "gay and cheerful." Id. at 35-36. Such distractions were out of the reach of the Bernsteins both before and during the war. 
At the time Gerhard Bernstein was entering the workforce, there were at least faint signs for the first time in a decade, that things might finally be starting to get better for the workers of Hamburg. Its economy, closely tied to those of Great Britain and the United States, recovered sooner and grew substantially faster than those of other German cities. With economic growth, workers' wages began to rise. By 1927, those wages had recovered to their pre-war levels. It must have been at least a cautiously hopeful time after the nightmare of the previous decade and a half..$^{9}$

Those hopes were soon dashed. Between the time that Herbert was conceived and the time he was born, the economic situation in Hamburg deteriorated badly. The Depression, which began in Hamburg in late 1929, a few months before Herbert's birth, hit the entire German economy hard. It proved particularly traumatic for the young. ${ }^{60}$ Industrial production fell by forty-two per cent, ${ }^{61}$ and it is estimated that almost half of all German workers were either fully or partially unemployed. ${ }^{62}$ The German government showed no sign that it had any idea what to do in the face of this pervasive and deepening crisis that radicalized much of the population, and disoriented and disillusioned even more of it. ${ }^{63}$

Hamburg, which had so conspicuously benefited in the 1920s from its economic ties to the Atlantic world, now just as conspicuously suffered as a result of them. During the time between Herbert's birth in 1930 and his second birthday in 1932, unemployment in Hamburg reached nearly forty per cent. ${ }^{64}$ In the ship building industry where his father worked, the situation must have been even worse. Gerhard Bernstein was among those who lost their jobs. It seems likely that his layoff, which happened before the Nazis came to power, was not racially motivated. He was, along with tens of thousands of other Hamburg workers, merely another victim of bad economic times.

Germany's economy began to recover soon after the Nazis seized power in January 1933, but the recovery in Hamburg was notably

59. Im Jahrzehnt der Wirtschaftskrisen [In the Decade of the Economic Crisis], Museum für Hamburgische Geschichte [Hamburg Museum], at http://www.hamburgmuseum.de/d/htm_d/ textversion/20jhd-1-07.html (last visited Oct. 4, 2002).

60. KERSHAW, HUBRIS, supra note 1, at 407-08 (citing the rise in youth suicide and criminality).

61. Id. at 404 .

62. Id.

63. Id. at 405-07.

64. Im Jahrzehnt der Wirtschaftskrisen, supra note 59. 
more sluggish. Unemployment in the city remained stubbornly high, and substantially worse than that in other large German cities. ${ }^{65}$ This higher unemployment rate was attributable, in large measure, to the economic policies pursued by the Nazis during their first three years in power. Those policies sought to build up German industrial capacity by restricting imports, and had a serious negative impact on Hamburg's international trade driven economy.

The ship building industry, and with it the larger economy of Hamburg, did not fully recover until the Nazis began their massive program of rearmament in $1936 .^{66}$ When the recovery came, Gerhard Bernstein was one of those left out. In fact, he would never again have steady, regular work for the rest of his life. If the decision to lay Gerhard Bernstein off during the depths of the economic crisis was probably not racially motivated, the decisions not to rehire him almost certainly were. The Nazis intended to rebuild the German economy and German military might, but they did not intend to have those whom they deemed to be Jews, or even Half-Jews, do the rebuilding. ${ }^{67}$

Herbert's mother, Käthe Franze, was not equipped to step in and fill the economic role that her husband could not. Women during the Weimar Republic were subjected to pervasive discrimination in employment. This discrimination increased sharply during the depression years immediately following Herbert's birth, and continued throughout the rest of the 1930s after the Nazis came to power. ${ }^{68}$ Not well educated, with a small child, there was little chance that Käthe would have been able to find regular work, and, in fact, she did not. What work she did was merely what she could find in hopes of supporting her small family. The Bernstein family had to make it through the 1930 s on very little.

\section{THE NUREMBERG LAWS}

In September 1935, the National Socialist Party faithful gathered to celebrate their annual ritual, the Reich Party Rally of Freedom. ${ }^{69}$

65. The overall unemployment rate in Hamburg at the beginning of 1934 was $40 \%$. Id.

66. See Auf dem Weg in die Kriegswirtschaft [Toward a War Economy], Museum für Hamburgische Geschichte [Hamburg Museum], at http://www.hamburgmuseum.de/d/htm_d/ textversion/20jhd-1-11.html (last visited Oct. 4, 2002).

67. See id. (discussing the negative impact that the ideological commitment to antiSemitism had on the Hamburg economy).

68. KERSHAW, HUBRIS, supra note 1 , at 408.

69. Id. at 566. The spectacle of the Nuremberg rallies was captured in Leni Riefenstahl's 
It was there that the Nazis promulgated the infamous Nuremberg Laws. These Laws as a group were designed to isolate Jews from participation in the civic life of the Reich, and to end sexual contact between Germans and German Jews. ${ }^{70}$ The implementing regulations for these laws then defined, for the first time, categories of people of partially Jewish descent, and attributed a legal status to them. ${ }^{71}$ Together, they would play a decisive role in Herbert Bernstein's life over the ensuing decade.

The Reich Citizenship Law established two categories of citizen: Reichsbürger and Staatsangehöriger. ${ }^{72}$ The law limited the status of Reichsbürger to those Staatsangehöriger, who were persons of "German and generically related blood." the term Staatsangehöriger was used to refer to the citizen of a Land, or state, within the Reich. The Nazis had, however, abolished the

1934 documentary film of that year's rally Triumph des Willens. For information about and clips from the film, see, Triumph of the Will, History Department of the University of San Diego, at http://history.sandiego.edu/gen/filmnotes/triumph.html (last modified Mar. 16, 1999). The film was re-released on June 18, 2002. The advertisement for it on the Amazon web site notes that "starring" in the film are "Adolf Hitler, Hermann Göring, et al.," at http://www.amazon.com/exec/obidos/tg/detail/-/B000065U6O/qid=1031841200/sr=1-1/ ref=sr_1_1/104-6561929-4973547? v=glance \&s=video.

70. There were three Nuremberg laws: Reichsflaggengesetz [The Reich Flag Law] v.15.9.1935 (RGB1.I S. 1145);Reichsbürgergesetz [The Reich Citizenship Law] v.15.9.1935 RGB1.I S. 1146) [hereinafter Reich Citizenship Law]; and the Gesetz zum Schutz des deutschen Blutes und der deutschen Ehre [Law for the Protection of German Blood and German Honor] v.15.9.1935 RGB1.I S. 1146-7) [hereinafter Blood Protection Law]. The Reich Flag Law established that the official colors of the Reich were the old imperial colors of red, black and white, and that the flag of the Reich was the swastika flag of the Nazi Party (Hakenkreutzflagge).

71. See Erste Verordnung zum Reichsbürgergesetz [First Regulation on the Reich Citizenship Law] v.14.11.1935 (RGB1.I S. 1333) [hereinafter First Regulation]. Section 2(2) of the First Regulation provided: A Jewish mixed race person is someone who is descended from one or two racially fully Jewish grandparents [Jüdischer Mischling ist, wer von einem oder zwei der Rasse nach volljüdischen Grosseltern abstammt]. The various categories of Mischling would in time be further divided into Mischling of the first and second grade, and into classes of privileged and non-privileged within each grade. The protocol of the Wannsee Conference, at which Nazi leaders met to plan the Final Solution, provides a record of how elaborate this classificatory system finally became. See Protokoll der "Wannsee-Konferenz" vom 20. January 1942 [Protocol of the "Wannsee Conference" of January 20, 1942], available at http:// www.ghwk.de/protdt.htm. [hereinafter Protocol of the Wannsee Conference]. For an attempt at explaining the terminology relating to persons of mixed Jewish ancestry, see German and National Socialist Terminology at http://www.rrz.uni-hamburg.de (last visited January 8, 2003).

72. When used in this context, both of these words translate into English as "citizen." See Bernstein, Reflections, supra note 4 , at 11.

73. See Reich Citizenship Law, supra note 70, at \$2(1) ["deutschen oder artverwandten Blutes"]. This new category constituted a change from the previous distinction used in Nazi discriminatory legislation of Aryan and non-Aryan. It was, even by Nazi standards, a bizarre category. The Foreign Office assured the Turkish government that Turks were regarded as "generically related." Bernstein, Reflections, supra note 4, at 14. 
Länder in $19344^{74}$ Limiting the residual category of persons, that is those not of "German and generically related" blood, to citizenship in political entities that no longer existed might appear to be another bad Nazi joke. ${ }^{75}$ In fact, the Nazis were using the term in an entirely new way to refer to a second class form of citizenship. ${ }^{76}$ What that citizenship entailed was not at all clear. ${ }^{77}$ What it did not entail soon was. Those who were only second class citizens could not vote, could not hold public office, and could not, assuming they wanted to, wave the Nazi flag. ${ }^{78}$

The Law for the Protection of German Blood and German Honor $^{79}$ (hereinafter referred to as the BPL) was an antimiscegenation law. It attempted to prevent the creation of racially mixed Jewish/German children by forbidding and criminally punishing both marriages and extra-marital sex between Jews and Germans, and by barring Jews from employing German females under the age of forty-five in their households. It was the first statutory expression ${ }^{80}$

74. Gesetz über den Neuaufbau des Reiches [Statute on the Reconstruction of the Reich] v.30.1.1934 (RGB1.I S. 75).

75. Herbert Bernstein argued that the provision of the Blood Protection Law (section 4) that made it criminal for Jews to display the German colors and flag, but guaranteed them the right to display Jewish colors, was such a bad joke, since there were no "Jewish colors." Bernstein, Reflections, supra note 4, at 13.

76. The leaders of the Jewish community at the time understood that this is what the Nazis intended to do when they made use of the familiar term "Staatsangehöriger" in a new way to create a previously unknown form of second class citizenship. See German Jewish Response to the Nuremberg Laws, Jüdische Rundschau, No. 77, September 24, 1935, available at http://www.us-israel.org/jsource/Holocaust/jewnurm.html.

77. The statute suggested that it did entail some sort of duties, since it defined a Staatsangehöriger as someone who was a member of the protective union of the German Reich [Staatsangehöriger ist, wer dem Schutzverband des Deutschen Reiches angehört], and who was thereby obligated to it [und ihm dafür besonders verpflichtet ist]. It provided that citizenship of both types would be defined by laws related to each as they were developed and promulgated. See Reich Citizenship Law, supra note 70, at §1(2).

78. See First Regulation, supra note 71.

79. Blood Protection Law, supra note 70.

80. It was not the first articulation of the view that Jews were a separate "race," and that racial identity was biological, not cultural. Article 4 of the Nazi Party Platform, presented to the Party at the Hofbräuhaus in Munich on February 24, 1920, and later declared "unalterable" reads: "Staatsbüger kann nur sein, wer Volksgenosse ist. Volksgenosse kann nur sein, wer deutschen Blutes ist, ohne Rüchtsichtnahme auf Konfession. Kein Jude kann daher Volksgenosse sein." [None but members of the nation may be citizens of the state. None but those of the German blood, whatever their creed, may be members of the nation. No Jew, therefore, may be a member of the nation.] On the promulgation and reception of the NSDAP Party Platform, see Kershaw, Hubris, supra note 1, at 144-45. The text of the Party Program was printed in pamphlet form and went through numerous editions. This text is taken from GOTTFRED FEDER, DAS PROGRAMM DER NSDAP UND SEINE WELTANSCHAULICHEN GRUNDGEDANKEn [The Program of the NSDAP and its Philosophical Principles] 17 (1933). 
of the Nazis' pseudo-scientific belief in a biological basis for their racial theories.

It was not at all clear at the time what the significance of these laws was. Some Jews welcomed them, particularly those provisions of the BPL forbidding intermarriage. ${ }^{81}$ More viewed them as "the heaviest of blows for Jews in Germany," but also as potentially a basis on which an accommodation might be worked out with the Nazi regime. $^{82}$ As with the initial flurry of anti-Jewish legislation in 1933, the Nuremberg laws followed a period of escalating violence directed at Jews, which, although certainly encouraged from the central Nazi leadership, was carried out locally and with local initiative. ${ }^{83}$ The Jüdische Rundschau expressed the hope that the laws might put an end to this "defamation and boycott" and create a basis for a "tolerable relationship" between Germans and Jews. ${ }^{84}$

These reactions were an attempt to make the best of a terrible situation. Jews in Germany in 1935 found themselves increasingly isolated ${ }^{85}$ in a state that had cast aside the rule of law as constituting any sort of limitation on its freedom of action, and which espoused no ideals to which they could appeal in an effort to dissuade it from taking yet more discriminatory actions against them. Nor was there reason to believe that appeal to the international community was likely to yield positive results. ${ }^{86}$ This was a time, Chaim Weizman noted, when the world was divided into two camps: those who wanted to expel the Jews, and those who refused to take them in. ${ }^{87}$

Immediately after the laws were enacted, it appeared that, in fact, there might be peace. It was not peace with justice, but at least

81. See Bernstein, Reflections, supra note 4, at 6.

82. See German Jewish Response to the Nuremberg Laws, supra note 76.

83. In addition, a number of local authorities passed discriminatory legislation against Jews, some of it quite amazing. One jurisdiction made it illegal to sell food to Jews. See William Zuckerman, Where the Ghetto Leads, THE NATION, Feb. 5, 1936, at 154, available at http://newdeal.feri.org/nation/na36154.htm.

84. See German Jewish Response to the Nuremberg Laws, supra note 76.

85. In an article that appeared in The Nation in February 1936, William Zuckerman saw with remarkable clarity the direction events would take in Germany over the next three years, dismissing as naive the belief that the Nuremberg laws might bring an end to the lawless attacks on Jews. He insisted that the Jews were not necessarily isolated if they could bring themselves to put aside their middle class prejudices, and make common cause with the working people of Germany. Zuckerman, supra note 83.

86. Id. (noting that even the friends of Jews in the international community naively believed that the Nuremberg laws might bring peace to the situation in Germany).

87. "The world is divided into two groups of nations - those that want to expel the Jews and those that do not want to receive them." JOSEPH L. BARON, A TREASURY OF JEWISH QUOTATIONS, 238 (n. rev. ed. 1965) (attributing the quotation to Chaim Weizmann). 
the tide of violence directed at Jews began to recede. No longer under the immediate pressure of constant harassment, many Jews concluded that they could live with the situation, and the numbers attempting to emigrate fell significantly. In fact, approximately sixteen thousand Jews who had already emigrated made the tragic decision to come back. ${ }^{88}$ The lull in the violence and harassment proved to be only temporary, and, by 1937, it was clear that the hope that the Nuremberg laws could serve as a basis for a workable relationship between Jews and the Nazi regime had proven groundless.

It seems implausible that five-year-old Herbert would have had any real awareness of the Nuremberg laws at the time they were enacted. He insisted, however, that by the time he was seven, he knew that these laws had special meaning for him and his family. ${ }^{89}$ They would, he later wrote, be the first laws he "encountered." had three memories of the ways in which he personally experienced the Nuremberg laws as a young child in the years before the war. None of the memories involved anything that could be understood as a direct legal consequence of the laws. Rather, they were part of a developing ethos in Germany that Jews were different, and were to be treated differently and worse than other people. ${ }^{91}$ The first memory related to his classes in a gymnastics club that his mother had enrolled him in. Käthe Bernstein was determined that her son would disprove the racial stereotype that Jews were not good at sports. Unfortunately for both of them, whatever the aptitude of Jews in general for sports, Herbert as an individual was bad at them. He tried all manner of excuses to get his mother to let him out of this twiceweekly humiliation, but with her greater size, authority and determination, she kept sending him back. Then one day he was rescued by the Nuremberg laws. ${ }^{92}$ He would not be permitted to continue to at-

88. Zuckerman, supra note 83.

89. Bernstein, Reflections, supra note 4.

90. Id. at 1 .

91. "The effect of the legislation upon the average law abiding German burgher ... has only been to put his legal conscience at rest. It is no longer verboten to bait the Jew, to persecute and humiliate him; so, therefore, it cannot be wrong. On with the hunt!" Zuckerman, supra note 83 .

92. Ironically, the group by-law that was promulgated to exclude him, supposedly in furtherance of the Nuremberg laws, was almost certainly invalid under them. Section 6(2) of the Reichsbürgergesetz provided that more stringent rules than those required in that statute, other statutes or the Nazi Party rules, none of which were implicated by Herbert's efforts in the gymnastics club, had to be authorized by the Ministry of the Interior and Hitler's deputy. As Herbert noted, no one, certainly not a person in his mother's position, would have dared to complain, and, in any case, he wasn't complaining. See Bernstein, Reflections, supra note 4, at 17 
tend the organization's functions, his mother was informed, because the group's by-laws limited membership to "pure Aryans." Herbert distinctly remembered how relieved he was to be the "victim" of such discrimination. ${ }^{93}$ The second incident was less welcome. Herbert attended school with "Aryan" children his age. One day in class, he was, along with other students, getting a little wild and noisy. The teacher singled him out for punishment. She let him know that he was only "tolerated" in the school and should not risk the consequences that might follow any new breaches of discipline. As she then put it, Herbert "should know why." 94 The third was less welcome still, the loss of his grandfather in 1937. Leopold Bernstein, as noted above, finally concluded that he would need to leave Germany and seven-year-old Herbert. ${ }^{95}$ Herbert believed that the Nuremberg laws were the final straw.

As an adult, in the months before his death, Herbert Bernstein was in the process of giving mature scholarly reflection to the significance of these laws. Although those thoughts were still preliminary and fragmentary, he had reached the definite conclusion that their impact was profound. ${ }^{96}$ Their importance, he believed, did not, however, rest on the direct discriminatory burden that these laws placed on Jews. Rather, it rested on the fact that in them the Nazis had committed the state to a racial definition of the society, and created the fairly precise term for determining who would be targets of exclusion from it. "Horrible as this may sound, it was in this purely instrumental respect that these laws did provide a 'central foundation' to the Holocaust, "necessary to carry on the later steps.",97

n.89.

93. The by-laws of the gymnastics club did not free Herbert altogether from participation in this hated activity. Gymnastic training was an integral part of the activities of the Hitler Youth, in which Herbert was compelled by law to participate, and of the schools that he attended. Much to his dismay, sports proved inescapable.

94. Again, the idea that it was appropriate to discriminate against him came out of the general atmosphere of state-authorized hostility, not from the specific provisions of any statute. In fact, he was not even subject to the quotas under the relevant law, the Statute on the Overcrowding of German Schools. Reichsgesetzblatt 1933 I., S 225. Apparently, it was enough for his teacher that he was "non-Aryan," and she was not alone in her beliefs. Hans Thielemann reports that shortly after the announcement of the Nuremberg laws there was a marked increase in anti-Jewish rhetoric at his school in Berlin, and his teacher gave the students in his class an assignment to produce a family tree showing that they were of Aryan descent. Thielemann, supra note 46 . Herbert, had he been given such an assignment, would have failed, since he was not.

95. Bernstein, Reflections, supra note 4, at 1.

96. Id. at 7.

97. Id. (quoting Peter Loewenberg). 
Although the Nuremberg laws relegated Jews to second class citizenship denying them the right to hold office or to vote, the nonsymbolic impact of the legislation was relatively slight. Except for a narrow class of persons exempted from the reach of the law by virtue of service in the First World War, non-Aryans had already been barred from holding public office, and the category of non-Aryans was even broader than that of not of "German or German related blood" used in the Nuremberg laws. Nor were the rights of voting, or the other privileges of citizenship, especially meaningful for those who enjoyed the status of Reichsbürger. By 1935, the Third Reich was a one-party state, ${ }^{98}$ in which voting had little meaning for anyone. The other usual privileges of citizenship in a modern state, such as freedom of expression and the right to petition for redress of grievances, had been abrogated in February, 1933 and were never restored under the Nazis. ${ }^{99}$ The Constitution provided no protection for anyone of whatever blood. Hitler, acting nominally as the Reich Cabinet, had the authority to promulgate laws that "deviated" from the Constitution without bothering to consult the legislature, or in fact anyone else. ${ }^{100}$ One's status as a first-class citizen provided no protection against arbitrary arrest and detention in concentration camps, and, by 1935, tens of thousands of Germans had been. ${ }^{101}$

The Nuremberg laws did not, moreover, announce some new principle that had never been articulated before. As noted above, the Nazi Party Platform had insisted both that Jews were a separate race, not merely a different religion or culture, and one that could never become a part of the German nation. ${ }^{102}$ What was new and critical was that this position was now articulated in a statute, and done so in a way that provided a set of definitions and categories that facilitated and shaped its implementation. It thus created the framework and the underlying rationale for each of the steps leading to the Holocaust. ${ }^{103}$

98. See Statute Against the Creation of New Political Parties, supra note 34. Section 1 declared that the Nazi Party was the only political party, thereby abolishing all of the other parties that were in existence at the time. Section 2 provided for the criminal punishment of anyone who subsequently attempted to establish another political party.

99. See Verordnung des Reichspräsident zum Schutz von Volk und Staat [Decree of the Reichs President relating to the Defense of the People and the State] v.28.2.1933 (RGB1.IS. 83).

100. Law for the Removal of the Distress of People and Reich, supra note 33 at v.24.3.1933. See also supra text accompanying note 34 .

101. KeRSHAW, HubRIS, supra note 1, at 459-60.

102. See FEDER, supra text accompanying note 80.

103. Bernstein, Reflections, supra note 4 , at 7. 
Those arbitrary definitions and categories unarguably had a direct impact on Herbert Bernstein's life. In the decrees implementing the Reich Citizenship Law and the BPL ${ }^{104}$ the Nazis created the legal category of Mischling to deal with persons of mixed ancestry. ${ }^{105}$ The decrees further set out which of these persons could be safely reabsorbed in the German Volk, without threatening the corruption of the race. The line was drawn at one Jewish grandparent. ${ }^{106}$

Herbert was thus classified as one of those non-Aryans whose descendants could be absorbed into the German race. As a nonAryan, he remained subject to all of the discriminatory legislation that affected non-Aryans. He could not become a member of the civil service, or work for the Reichsbank or the rail system. But he was entitled to hoist the Nazi flag, and was required to join the Hitler Youth. Unless the rules changed, if he married a German woman, his children would not be subject to the restrictions that he would have to suffer. But the fact that he enjoyed a special status could not protect his father, or his Bernstein relatives. Nor were the race laws the only threat that he faced as a result of the unhappy fact that he was a child in the Third Reich. At 4:30 in the morning of September 1, 1939, Germany invaded Poland. Two days later, Great Britain declared war on Germany. It was a war that ultimately would free Herbert Bernstein from the world of the Nuremberg laws, and the limited place in society that the Nazis had relegated him to. But he would experience a lot of hardship in the six years between that invasion, and the final destruction of the Third Reich.

104. First Regulation, supra note 71; Blood Protection Law, supra note 70, v.14.11.1935 (RGB1.I S. 1334).

105. A Mischling was a person with one or two "in the racial sense" fully Jewish grandparents. A grandparent was considered fully Jewish if he belonged to a Jewish religious community." First Regulation, supra note 71, at $\S 2(2), 5(1)$. The definition thus actually contained elements of the racial definition insisted on by the Nazi Party Platform, and the cultural/religious affiliation relied on the definition of non-Aryan in the first decree implementing the Professional Civil Service Law in 1933. The Wannsee Protocol, apparently relying on some combination of doubt about the reliability of evidence relating to ancestry, and possibly fears about particularly virulent strains of Jewish blood, provided that Mischling of the second class were to be treated as Jews if they had features that were "especially unappealing racially." See Protocol of the Wannsee Conference, supra note 71, at \$4(2)(b).

106. Mischling with one Jewish grandparent did not require a special license from the Minister of the Interior in order to marry a German, but did require one to marry a Jew, or a Mischling with two Jewish grandparents. They were not supposed to marry another Mischling with one Jewish grandparent ["soll nicht gesclossen werden"], but did not require a license to do so. Blood Protection Law, supra note 104. The clear intent of the regulations was to insure that the blood that had been contaminated by intermarriage with Jews would be diluted to a level that no longer constituted a threat. 


\section{LISTENING TO THE BBC}

Herbert's family, for fairly obvious reasons, developed a deep skepticism about information put out by the government. They turned instead to the $\mathrm{BBC},{ }^{107}$ and continued to listen to it, albeit cautiously and with a watchful eye on their neighbors, throughout the war. $^{108}$ It was, Herbert told me, a source not only of information, but also of hope, especially following the arrests of various members of his family.

In the wake of the repeated bombings visited by the British on Hamburg, and the repeated destruction of their own living quarters in those bombings, it would have seemed natural to me if the Bernsteins had felt anger and resentment toward the Allies, and discontinued the practice. Herbert insisted that he, at least, did not, not even as he picked his way through the remnants of yet another apartment, trying to salvage what he could. It was clear to him at time, he told me, that the British were merely doing unto Hamburg, what had been done to them. He wanted no part of yet another round of reprisals and revenge. $^{109}$ The members of the circle in which he lived were convinced that after the winter of 1942, the Allies would win sooner or later. He

107. The British Broadcasting Corporation (BBC) began the European Service with broadcasts in German on September 27, 1938. See Trevor Worthy, The Unofficial Guide to the BBC, British Broadcasting Corporation, at http://www.vaxxine.com/mastercontrol/BBC/ chapters/Dates.html (last modified Mar. 26, 2000). See also Geoffrey Wheatcroft, Who Needs the $B B C$, ATLANTIC MONTHLy, March 2001, at 53.

108. Listening to the $\mathrm{BBC}$ constituted, along with spreading rumors and making jokes about the Nazi regime, the criminal act of treachery (Heimtuckeangelelegenheiten). It was a charge used against persons not associated with any organized opposition to the regime such as the Communists or Social Democrats. During April, May and June, 1944, an average of approximately 1,500 Germans a month were arrested for treachery. See GABRIEL A. AlmOND \& Wolfgang Krauss, The Size and Composition of the Anti-Nazi Opposition in Germany, PSOnline (Sept. 1999), http://apsanet.org/PS/sept99/almond.cfm (including introductory notes by the author). This report was prepared in connection with the HAMBURG FIELD REPORT, supra note 12, immediately following the war. The original manuscript is in the National Archives in Washington. For an account of a German family that similarly relied on the BBC to discover what was happening around them before and during the war, see Thielemann, supra note 46.

109. A much fuller, but remarkably similar, articulation of these same sentiments was published in a pamphlet put out by the NKFD (Nationalkommittee Freies Deutschlands, or National Committee for a Free Germany) in Leipzig in December, 1943, in an effort to counter Nazi propaganda efforts to rally Germans to the war effort by denouncing the Luftterror visited on Germany by the Allies. The NKFD was an opposition group founded at the Krasnogorsk prisoner of war camp in July, 1943. The Leipzig chapter was founded in September, 1943. Almond \& Krauss, supra note 108. In the aftermath of Operation Gomorrah, Hitler suggested that his propaganda people tell the German public that the Luftwaffe had successfully mined the Humber estuary: "'You only break terror through terror! Everything else is rubbish."' IAN KeRSHAW, HitLER, 1936-1945: NemESIS 598 (2000) [hereinafter KERSHAw, NEMESIS]. 
listened to the $\mathrm{BBC}$ hoping for the reports that their victory would come sooner rather than later, and before it was too late for him, and his family and the people of Germany.

\section{A CIVILIAN IN THE AGE OF AIR POWER}

Most contemporary observers agreed that there was no enthusiasm among the German population in 1939 for another war. ${ }^{110}$ William Shirer, an American correspondent writing from Berlin on August 31, 1939, thought that the Nazis would not actually go to war "with a population so dead set against it." 111 What Shirer failed to understand was that the hopes and fears of ordinary citizens did not matter much in Nazi Germany, and they "were powerless to affect the course of events." War would and did come, with or without the enthusiasm and blessing of ordinary Germans. Those ordinary Germans had strong reason to believe that the consequences for them would be bad. The preparations for war, begun as early as 1935, made it clear that in this conflict everyone would be vulnerable. ${ }^{113}$

In the First World War, after the extraordinarily rapid movement of German troops through nearly all of Belgium in the initial weeks of the conflict, the front in the West stabilized and moved very little for the rest of the war. Conditions and casualty rates along that front were appalling for both sides, but most civilians, even those just a short distance away, were relatively safe from violent death. ${ }^{114}$ The British naval blockade of Germany did produce catastrophic shortages of food and other essential materials, but defensive tactics of both sides were too well developed to permit the armies of either successfully to penetrate the front.

110. KeRSHAW, NEMESIS, supra note 109, at 200-21.

111. Id. at 221.

112. $I d$.

113. See Hamburg im Krieg [Hamburg During the War], Museum für Hamburgische Geschichte [Hamburg Museum], at http://www.hamburgmuseum.de $/ \mathrm{d} / \mathrm{htm} \_\mathrm{d} /$ textversion/20jhd1-13.html (last visited Oct. 4, 2002) (explaining that air raid exercises started in Hamburg in 1935, and blackout exercises two years later).

114. The situation in the east was less secure, both because there was greater movement in the front, and because civil war broke out in Russia and destroyed the ability of the Czarist government to control events. Some commentators estimate the number of civilian casualties in Russia during and immediately after the First World War at two million. See THE EUROPEAN POWERS IN THE FIRST WORLD WAR (Spencer C. Tucker, et al., eds., 1999). J. Bradford DeLong gives total military casualties in the First World War as ten million killed and twenty-one million wounded out of sixty-five million men mobilized, and total civilian casualties as a tenth that number. He estimates that during the Second World War civilian casualties exceeded military casualties. See J. BRADFORD DeLONG, SLOUChING TowARdS UTOPIA?: THE ECONOMIC 
There were air attacks, and they did result in civilian casualties. One raid by German bi-planes on London on June 13, 1917 resulted in 97 deaths and injured 439 others. ${ }^{115}$ The aircraft that carried out these raids were, however, too primitive to do sustained extensive damage. It was readily apparent that as aircraft got better, things would be much worse for civilians in the next war. ${ }^{116}$ Stanley Baldwin explained the new reality in stark terms in a speech to the House of Commons:

I think it is well ... for the man in the street to realise that there is no power on earth that can prevent him from being bombed. Whatever people may tell him, the bomber will always get through. ${ }^{11}$

The relative safety of civilian populations behind the front lines was a relic of the past.

The British government, recognizing this change in the reality of warfare, started making plans to evacuate women and children from cities and towns as early as the mid 1930s. In July 1939, fearing that Germany would attack from the air prior to an all-out invasion that it assumed would be imminent, the Chamberlain administration began taking active measures to prepare for the mass evacuation of school children from urban areas. ${ }^{118}$ Those plans were put into effect following Germany's invasion of Poland on September 1, 1939. ${ }^{119}$ The actual evacuation began on September 3, the day that Britain declared war on Germany. ${ }^{120}$ The Chamberlain government had, how-

HISTORY OF THE TWENTIETH CENTURY 8 (February 1997) (unpublished manuscript), available at http://econ161.berkeley.edu/TCEH/Slouch_WWI10.html.

115. See The Popular Outrage, at http://www.btinternet.com/ eastlondonpostcard/Nov01. htm.

116. "As early as May 1924 a sub-committee of the Committee of Imperial Defense [in Britain] began a study of air raid pre-cautions." Blitz Web Exhibition, Museum of London, at http:// www.museum-london.org.uk/MOLsite/exhibits/blitz/prepare/prepare.htm (last modified March 12, 2002).

117. $I d$.

118. Children and the War: An Overview, Holnet: London at War 1939 - 1945, at www.holnet.org.uk/learningzone/londonatwar/childrenthewar/index.html (last visited Oct. 4, 2002).

119. Adolf Hitler, Proclamation to the German Army (September 1, 1939), available at http://www.yale.edu/lawweb/avalon/wwii/gp1.htm.

120. On the declaration of war, see Neville Chamberlain, Address in the House of Commons (September 1, 1939), available at http://www.yale.edu/lawweb/avalon/wwii/gb1.htm; Communication from the German Government to the British Government-September 3, 1939, available at http://www.yale.edu/lawweb/avalon/wwii/gp3.htm; Neville Chamberlain, Address in the House of Commons (September 3, 1939), available at http://www.yale.edu/lawweb/ avalon/wwii/gb2.htm. On the beginning of the evacuation of children from London, see Children and the War: An Overview, supra note 118. The scale of the operation was extraordinary. 827,000 school children and 103,000 teachers, 524,000 children below school age along with their 
ever, overestimated the capability of their adversary. The feared air attacks on London did not come, or rather did not come in $1939 .{ }^{121}$

It does not appear that the German government gave anything like the same attention to the desirability of evacuating German children as the British government had given to evacuating British children. ${ }^{122}$ Their efforts were concentrated instead on developing defense systems to protect the cities from attack, and shelters to protect the citizens if the air attack succeeded. ${ }^{123}$ This difference in approach may have reflected a certain failure of the imagination on the part of the leadership of the Nazi government. Through the initial phases of the Battle of Britain, the Nazis appear to have thought in terms of attacking, not of being attacked. ${ }^{124}$ Less thought, therefore, may have been given to the consequences air war for the civilian population, even if it could be protected from the immediate impact of bombing.

The retaliatory raid on Berlin in immediate response to the initial attack on London made it clear, however, that the Reich could be bombed. ${ }^{125}$ By mid-September, 1940, it was becoming obvious that

mothers, and 12,000 pregnant women were all evacuated. Id.

121. In fact, British bombers successfully attacked German cities, before British cities came under attack from the Luftwaffe. In an effort to counter the German offensive in the West, British Bomber Command targeted sites in the Rhine/Ruhr industrial area as early as May, 1940. Introduction, Battle of the Ruhr, Historical Center Hagen at http://www.hco.hagen.de/ ruhr/uk/uk-1.htm (last visited Oct. 4, 2002). For an account of the impact of these early raids on the city of Hagen, see Die Stadthagen im Zweiten Welt Krieg [The City of Hagen in the Second World War], Historical Center Hagen at www.hco.hagen.de/ns-zeit/hagen/index.html (last visited Oct. 4, 2002). These early attacks were fairly modest in scale and limited largely to military and industrial targets. When the Germans finally did begin their attacks on Britain in July 1940, theirs followed this same pattern. In the middle of August 1940, the first element in that pattern changed dramatically. The previously scattered attacks on airfields and aircraft manufacturing facilities became dramatically more massive and intense. In the first week in September 1940, the second element in the pattern changed as the Luftwaffe turned its massive attacks on British cities and their civilian populations.

122. The HAMBURG FIELD REPORT noted that the practice of sending city children to the countryside for vacations, begun as early as 1915 , and later put under the authority of the Nationalsozialistische Volkswohlfahrt, the Nazi welfare organization, formed the basic organizational pattern for the later developed plan to evacuate children from potential target areas. HAMBURG FIELD REPORT, supra note 12, at 156.

123. If the German government gave less attention to the issue of evacuation, it probably gave more attention to the provision of air raid shelters. The protocols relating to those shelters were, unlike those in Britain, calculated to save lives at the expense of property damage. $I d$. at 16.

124. "Göring had once joked that should British planes ever reach Germany, his name was not Hermann Göring, but Hermann Meier." After the bombing of Berlin on August 25, 1940, the night after the first massive Luftwaffe raid on the East End of London, Berliners took to calling him "Herr Meier." KERSHAW, NEMESIS, supra note 109, at 309.

125. Hitler, in keeping with his usual response to being threatened, promised massive retaliation for the retaliatory British raid. "We'll wipe out their cities! We'll put an end to the 
the air campaign had not succeeded in destroying either the Royal Air Force or the will of the British people to resist, and that it was likely that German cities and German civilians increasingly were going to come under attack. In Hamburg, it was clear even earlier. By August 3, approximately fifty air raid warnings had sent the residents of the city down into the air raid shelters for safety. ${ }^{126}$

\section{THE KINDERLANDVERSCHICKUNG ${ }^{127}$}

On September 27, 1940, Adolf Hitler issued a Führerbefehl calling for the voluntary evacuation of children from areas likely to be subject to bombing. ${ }^{128}$ This was then followed by an intensive campaign in the press and on radio to encourage parents to agree to send their children to safer areas. ${ }^{129}$ The campaign undoubtedly found a receptive audience among the parents of Hamburg. The initial British air raids did not inflict extensive damage, but the air raid warnings proved extraordinarily disruptive to the lives of those in the city. ${ }^{130}$ There were nearly two hundred air warnings in Hamburg during the second half of 1940, each of which required parents to drag their children from their beds and into the shelters. ${ }^{131}$ Children suffered greatly from this routine, especially when it was repeated for several nights in a row. ${ }^{132}$ Those, like Herbert who were of school age were seldom in any condition to study after spending the night in an air raid shelter, and the government was forced to pass a law delaying the start of school until ten o'clock on the day following one of these alarms. ${ }^{133}$ In hopes of saving their children and themselves from this disruption, the parents of approximately 80,000 Hamburg children agreed to have them sent to the interior of the Reich. ${ }^{134}$ The organiza-

work of these night pirates." Id. at 309.

126. WOLFF-MÖNCKEBERG, supra note 8, at 38. During all of 1940, there were 78 actual air raids on the city. HAMBURG FIELD REPORT, supra note 12, at 2.

127. Translated literally, it means the sending of children into the countryside. Early in the war, it was a genuinely voluntary program, and there was a high level of parental cooperation. After 1943, it became increasingly coercive and encountered greater resistance from parents.

128. The actual order was issued by Reichsleiter Martin Bormann. The evacuation began on October 3, 1940. Authority for organizing the Kinderlandverschickung was entrusted to the Nationalsozialistische Volkswohlfahrt under the leadership of Baldur von Schirach, available at http://www.dhm.de/lemo/html/dokumente/klv/index.html.

129. HAMBURG FIELD REPORT, supra note 12, at 156.

130. See WOLFF-MÖNCKEBERG, supra note 8 , at 38 .

131. Id.

132. Id.

133. Id.

134. HAMBURg Field REPORT, supra note 12, at 156. See WOLFF-MÖNCKEBERG, supra 
tional unit was the school class, and the children generally were sent together along with their teacher. Ten-year-old Herbert Bernstein and his classmates were in that first group of evacuees, and were sent across the country to the pilgrimage town of Altötting in Bavaria. ${ }^{135}$

\section{ENCOUNTERING CATHOLIC BAVARIA}

Most of the children who were sent from Hamburg to the countryside as part of the Kinderlandverschickung recalled the experience, as adults, with great fondness. In their memories, at least, it was "eine schoene Zeit," a beautiful time. ${ }^{136}$ In comparison with the fear engendered and the disruption caused by bombing raids, the quiet life in the villages of the interior must have been a welcome relief. If the children had to cope with being taken from their homes and parents, they were at least going with their classmates, and often, entire schools. They were, moreover, under the familiar and hopefully comforting supervision of their teachers. ${ }^{137}$ Herbert did not so remember his experience. At age 71, in the final months of before his death, he still recalled it as one of the difficult times of his life. He did not remember peaceful countryside and freedom from bombing. He remembered the feeling of being an unwanted outsider in a very foreign place. $^{138}$

note 8 , at 38 ("since late autumn most teachers and school children have been evacuated to safer districts").

135. Many of the records related to the operation of the Kinderlandverschickung in Hamburg were destroyed during the war. There are about 180 files from the Hamburg Entsendungsgau in the Hamburg Staatsarchiv that may contain information about Herbert Bernstein, but they are unpublished and I was unable to get access to them. See E-mail from Erich Maylahn, 2.Vorsitzender [vice-chairman] der Dokumentations-Arbeitsgemeinschaft KLV e.V. [Vice-Chairman of the Kinderlandverschickang Documents Study Group], to Paul Haagen, Professor, Duke University School of Law (March 5, 2002) (on file with author). There are apparently no surviving records in Altötting relating to the Hamburg children. See E-mail from Richard Bauer, Einwohnermeldeamt Altötting [Residents' Registration Office of Altötting Bavaria], to Paul Haagen, Professor, Duke University School of Law, (March 18, 2002) (on file with author).

136. See E-mail from Erich Maylahn, supra note 135.

137. In addition to trying to make certain that the children had the support of their teacher and classmates, the authorities also made serious efforts to insure that they had adequate health care. $I d$.

138. The way in which I learned of Herbert's experiences in Altötting was typical of the way in which I learned about many of the things in his past. My secretary, Frances Hamacher, was leaving for a bicycling trip in Germany and Austria. In the course of discussing the trip with her, I told her about a weekend that I had spent with a friend from the Max-Planck-Institut für Biochemie at a farmhouse in Bavaria. Herbert asked me where it was, and I told him Altötting. He recalled his own very different experiences there, and then went back to work.

It seems likely that Herbert's awareness that his personal background meant that he was 
Under the best of circumstances, ten-year-old Herbert Bernstein's initial encounter with Catholic Bavaria would have been a difficult and wrenching experience. His leaving was not under the best of circumstances. It was his first time away from home and his parents. He had left under frightening conditions, unclear about the dangers that his parents were about to be exposed to, at a time when it was not at all clear whether the danger to them was greater from the sky or their own government. The allied bombing of Hamburg had begun, and one of his grandfathers and his father's two brothers had already reached the conclusion that they had to flee Germany. He can have had no way of knowing what might happen to his parents while he was gone, and what would happen to him if something did.

The place that he was leaving, the only world that he had known, was a cosmopolitan, commercial center. The place he was going was about as different as any place in Germany could have been. ${ }^{139}$ Even the language there, Herbert recalled, seemed only superficially similar to the one spoken in his native city, and initially he had a great deal of trouble understanding it. He and his classmates were going more than across the Reich. They were going from possibly the most liberal, western-oriented, Protestant places in Germany, to Bavaria, the most Catholic and traditional. They were, moreover, being sent to the most Catholic and traditional of places in Bavaria, the pilgrimage town of Altötting, ${ }^{140}$ and to a convent, the most Catholic, conservative and traditional of institutions in the town. ${ }^{141}$

only "tolerated," which had been forcefully impressed on him several years earlier by his teacher in Hamburg, must have greatly increased his anxiety when he encountered both hostility and a world that he could not understand.

139. After the mass evacuation of Hamburg in July, 1943, it was reported that those who were sent to countryside in the vicinity of Hamburg were received remarkably warmly by the local inhabitants, but those sent to Bavaria encountered considerable hostility from the local population, who referred to the refugees derisively as "Bombenpack Preussen," "a pack of bombed out Prussians." Martin Middlebrook, The Battle OF HAMbURG 358 (1981). It is likely that the Hamburg children encountered an analogous, if probably more muted, reaction two and a half years earlier.

140. At the time Herbert arrived in Altötting, it was a village of about six thousand inhabitants. "Bis zum Beginn des Zweiten Weltkrieges zählte Altötting etwa 6,000 Einwohner." "At the beginning of the Second World War Altötting had approximately 6,000 inhabitants." City of Altötting in the heart of Bavaria at http://www.altoetting.de.

141. It appears that Herbert was housed in either the Kreszentiaheim on Kreszentiaheimstrasse near the Gnadenkappelle, or in the nearby Franziskushaus on Neuöttingerstrasse. See E-mail from Richard Bauer, supra note 135. From Herbert's description, it seems marginally more likely that it was the Kreszentiaheim, but it is difficult to have any confidence in that conclusion. See id. 
Under ideal conditions and with the best of will, the experience would have been a trying one for all concerned. Herbert recalled it as profoundly disorienting. It must have been a serious trial for the nuns as well. The imposition of any group of children would have been a major disruption to their religious, communal lives. The fact that the imposition was of a group of non-Catholic children from the very foreign world of northwest Germany would have made it all the more difficult to bear. ${ }^{142}$ The uncertainty about how long these children would be staying would have further added to the sense of anxiety for both groups. These were not, however, ideal conditions and the will was more ill than good. In one of those bits of horrendous timing that seemed to have plagued Herbert Bernstein's early life, the arrival of the children coincided with greatly heightened tensions between the Catholic Church in Bavaria and the Nazi Party.

The relationship between the Nazi Party and the Christian, and especially Catholic Churches, was never better than ambivalent. ${ }^{143}$ If the Churches initially were comforted by the anti-communism of the Nazis, and hopeful that the Party might lead to the moral revitalization of a demoralized Germany, ${ }^{144}$ they were also horrified by the Nazis' attitude toward the weak, ${ }^{145}$ and worried about the exclusivity of the demands that the Nazis made on the loyalty of their adherents. The Nazis, in turn, showed great concern that the Christian Churches continued to command the loyalty of believers and to serve as an alternative source of authority within the state. ${ }^{146}$ Nazi rhetoric against the Churches was frequently violent. ${ }^{147}$ In early 1937, Hitler declared that "Christianity was ripe for destruction" and that "at some point in the future ... the entire force of the Party [would be] turned to the destruction of the clerics." ${ }^{148}$

142. Refugees from northwest Germany were, in general, not well received in Bavaria, where they were perceived as outsiders. My own experience as an American student living in Bavaria in the summer of 1974 suggested just how strongly rural Bavarians associated the word Prussian with unacceptable outsiders. My failure to understand some rule of etiquette in a Bierstube in the town of Burghausen, close to Altötting, led the locals to dismiss me not as an American, but as a "Prussian."

143. KeRSHAw, HUBRIS, supra note 1 , at $432,436$.

144. Id at 432 .

145. KERSHAW, NEMESIS, supra note 109, at 252-61 (discussing the Nazi euthanasia program and the Churches' resistance to it).

146. KeRSHAw, HUBRIS, supra note 1, at 436.

147. In January, 1925, Erich von Ludendorff's attacks on the Catholic Church became so extreme that even Hitler had to take steps to distance himself from them. Id. at 262.

148. KeRSHAw, NEMESIS, supra note 109 , at 40 . Nor was the violence merely rhetorical. In 1937, Goebbels orchestrated a series of "immorality trials" against Franciscans. Id. 
Few in the Party were more committed to this radical antiChristian policy than the Gauleiter of Upper Bavaria and Bavarian Education and Interior Minister, Adolf Wagner. ${ }^{149}$ Despite repeated warnings from Hitler that the time was not yet ripe for open conflict with the Churches ${ }^{150}$ Wagner seized on encouragement from others in the Party hierarchy, especially Martin Bormann, to initiate an assault on the Catholic Church in Bavaria. ${ }^{151}$ Church publications were banned. Monastic properties were confiscated or sequestered for use on behalf of refugees, like the children from Hamburg. Nuns were replaced by the "brown shirt sisters" of the Nationalsozialistische Volkswohlfahrt, the Nazi welfare organization. There were attempts to abolish school prayers and remove crucifixes from the schools. Party officials even interfered with the Church calendar, shifting feast days to Sundays. ${ }^{152}$

The reaction in Bavaria against these policies got so strong that Hitler was forced to step in and restrain Wagner. ${ }^{153}$ The restraint, such as it was, did not come in time to help Herbert. He had been dropped into a hornet's nest of anger and suspicion, and would feel the wrath of the religious and civic community of Altötting for the entire length of his stay. In the eyes of the nuns, the fact that Herbert and his fellow classmates wore the black uniforms of the Jungvolk made it clear that they were the other. This identity that had been thrust on Herbert, ${ }^{154}$ and for which he felt no personal affiliation, be-

149. Id.

150. Id. at 39,424 .

151. Id. at 425 .

152. Id. at 424-25. As with much else in a government that operated according to the notion of "working toward the Führer," it was not always easy to determine who was actually doing what according to what authority. Wagner later claimed that he was acting under the authority of Reichsleiter Bormann " "to give visible effect to the teaching ... that Socialism and Christianity are irreconcilable opposites." Id. at 424 . Kershaw concludes that Wagner had probably misinterpreted "Hitler's repeated rantings." Id. Given his own predilections, Wagner had every reason to engage in an expansive interpretation of those rantings. On the operation of the concept of working toward the Führer, see KERSHAw, HUBRIS, supra note 1, at 527-91.

153. KeRSHAW, NEMESIS, supra note 109, at 428-29. Kershaw notes that it was only the need to act pragmatically that induced Hitler to restrain the radicals, and that Hitler made it plain that he fully approved of the closing of the monasteries. Kershaw adds: "Events in the Warthegau (where, by 1941, 94 percent of churches and chapels in the Posen-Gnesen diocese were closed, 11 percent of the clergy murdered, and most of the remainder thrust into prisons and concentration camps) showed the face of the future." Id. at 428.

154. Gesetz über die Hitlerjugend [Law on the Hitler Youth], v.1.12.1936 (RGB1.I S. 993), implemented by Zweite Durchführungsverordnung ... (Jugenddienstverordnung )[The Second Implementing Regulation... (Youth Service Decree)], v.25.3.1939 (RGB1.I S. 710) (requiring every German boy over the age of ten to join the Deutsches Jungvolk, a junior affiliate of the Hitler youth). Herbert was ten at the time that he was sent to Altötting. 
came a reason to mistreat him.

Recalling those months sixty years after the event, Herbert could no longer remember in any detail the various slights and indignities to which he had been subjected. What he could recall with distressing clarity was the iconography of this very different world. ${ }^{155}$ The images of Marian Christianity that he discovered in Altötting had no analogues in the austere simplicity of the North, and they frightened him. He distinctly remembered lying on his bed in the convent with moonlight streaming in his window illuminating a picture of the suffering Christ that hung in his room. He recalled lying there night after night exhausted, but too frightened to shut his eyes. He recalled wanting to get up and turn the picture around so that it faced the wall and not him, but being too frightened of the nuns to dare. Sixty years later, as he recalled that image, he shuddered visibly.

When the British began the evacuation of children from London the day that Britain declared war on the Third Reich, they overestimated the imminence of the German threat from the air. With no bombs falling around them, parents quite naturally started bringing their children home and reuniting their families. By the late spring of 1940, approximately three quarters of the children and mothers who had been evacuated had returned to London. Something quite similar happened with the first group of children evacuated from Hamburg in the Kinderlandverschickung a year later. The air raids that so tortured the sleep of the children of Hamburg in the late summer and early fall of 1940 became increasingly less frequent in early $1941 . .^{156}$ Gradually, one by one, the parents of Herbert's classmates made their way to Altötting to collect their offspring. Gradually, the size of the contingent of Hamburg children in the convent dwindled. Herbert's parents did not come to get him, and apparently did not explain why. Herbert told me that he assumed the problem was that they did not have the resources to come and get him, but while he tended to be very clear and specific on most matters related to his experiences during the war, he was always notably vague on this matter. What he was not vague about was the emotion of feeling abandoned as he watched the other children gathered up one by one and brought

155. See J. Issickener, Buchlein der Zupfluct der Maria [Little Book of Seeking Refuge in Mary](1497), available at http://www.godecookery.com/macabre/gallery5/macabre5.htm (last visited Oct. 4, 2002) (to view The Altar of the Virgin of Alt-Oetting, an example of the sort of icongraphy that so distressed him at the time).

156. In 1940, there were 78 air raids on Hamburg. In 1941 and 1942 combined, there were 48. HAMBURG FIELD REPORT, supra note 12, at 2. 
home, while he remained in Altötting to face the picture of the suffering Christ.

Eventually, someone did come to get him in the late spring of 1941 and he thankfully returned to Hamburg. The bad timing that afflicted his early life surfaced again. Just as those who returned to London in the spring of 1940 had to face the Blitz that fall, Herbert managed to return to Hamburg in time to face what an American intelligence report concluded was "the worst holocaust in history."157

\section{DISCOVERING THE CONSEQUENCES OF RACIAL CATEGORIES}

In 1942, twelve-year-old Herbert and his father took a sad rail journey from Hamburg to Berlin. ${ }^{158}$ They were traveling there to say goodbye to Gerhard's sister Erna, her husband, Herbert's grandfather Leopold Bernstein's sister, and several other Bernstein relatives. All of them had received their deportation orders and were about to be sent to the east. Because they were leaving the Reich, albeit involuntarily under compulsion of law, their property would be confiscated as soon as they left. ${ }^{159}$ Some time after Herbert and his father returned to Hamburg and the rapidly dwindling Bernstein presence there, Gerhard was himself arrested and sent to Neuengamme. At age twelve, Herbert had to assume the role of male head of the Bernstein family. He was all that was left in Hamburg. His father, grandfather and uncles all had been imprisoned or had fled the Reich.

The Neuengamme camp, where Gerhard Bernstein was interned, was first established in December 1938, when an SS unit based at Sachsenhausen transferred one hundred prisoners to an abandoned

157. Id. at 31. The use of the word "holocaust" to describe what happened to Hamburg may seem jarring to modern readers, who have come to associate the term with the Nazi genocide. The American researchers were not making any sort of comparison between that genocide and the Allied destruction of Hamburg. They used the term to mean an all-consuming fire.

158. The account of that trip and the analysis of the Nazi regulations relating to racial status draws heavily on Herbert Bernstein's unfinished manuscript, Bernstein, Reflections, supra note 4, at 17.

159. Persons deemed Jews had a second class form of citizenship known as Staatsangehörigkeit, as opposed to full citizenship of Reichsangehörigkeit. Elfte Durchführungsverordnung zum Reichsbürgergesetz [The Eleventh Regulation for the Implementation of the Reichsbürgergesetz] v.25.11.1941 (RGB1.I S.722). The Eleventh Regulation for the Implementation of the Reichsbürgergesetz provided that persons who possessed only Staatsangehörigkeit lost all rights of citizenship if they left Germany. Property of such persons was subject to being seized by the state. The Eleventh Regulation was interpreted to apply to Jews forcibly deported to concentration camps outside the Reich. Bernstein, Reflections, supra note 4 , at 4. 
brickworks near Hamburg. ${ }^{160}$ The SS intended to re-open the brickworks and use the inmates to supply bricks for the Führer buildings that were scheduled to be constructed as part of the Nazis' plans for redevelopment of the Elbe. The camp was not, however, destined to play such a modest role. By June 4, 1940, Neuengamme already had approximately 2,000 inmates, and was reorganized as an independent concentration camp. ${ }^{161}$ At the time of Gerhard's arrest in 1942, it had dramatically increased in size, and its role was changing again. To accommodate the large number of new inmates sent to the camp, satellite camps administered from Neuengamme were set up throughout the region. Eventually, there would be ninety-six of these satellite camps. ${ }^{162}$ According to Herbert, his father spent most of the time that he was interned in one of these camps in Schleswig Holstein.

Although never organized as a death camp, Neuengamme saw more than its share of death. Sanitary conditions at the camp were appalling, and there was an almost total lack of medical care. ${ }^{163}$ The provision of food and shelter was wholly inadequate, especially after the sharp increase in the number of inmates sent there beginning in 1942. This neglect and mismanagement were then supplemented by harassment and abuse of the prisoners by SS guards and their helpers, and thousands of cases of outright murder. ${ }^{164}$ Almost $60 \%$ of the 95,000 persons sent to the camp between 1940 and 1945 died there. ${ }^{165}$

Beginning in 1942, some Neuengamme inmates were used in armaments production. The percentage of those so engaged increased over the course of the remainder of the war, and may, after 1944, have been the majority of them. ${ }^{166}$ According to Herbert, his father was not involved in this activity. He was assigned to dig graves. There would have been no shortage of work given the death rate at the camp. In addition, Neuengamme inmates were also used to help clear up wreckage and remove bodies after the air raids on Hamburg

160. See Concentration Camp Memorial Neuengamme, at http://www.hamburg.de/ Neuengamme/welcome.en.html (last visited Oct. 4, 2002); Vincent Chatel \& Chuck Ferree, Neuengamme, The Forgotten Camps, at http://jewishgen.org/FogottenCamps/Camps/ NeuengammeEng/html (last modified July 16, 2002).

161. Erna and her husband were initially sent to Theresienstadt in what is now the Czech Republic. He was then sent on to one of the death camps. Which one, I do not know, and Herbert may not have known. Of all of the Bernstein relatives sent to the east, only Erna survived.

162. See Chatel \& Ferree, supra note 160.

163. Id.

164. Concentration Camp Memorial Neuengamme, supra note 160.

165. See Chatel \& Ferree, supra note 160.

166. Id. 
and surrounding areas. ${ }^{167}$ In one of those ironic reversals of racial stereotyping and prejudice, the leader of the street cleaning department (Aufräumamt) explained to the investigators from the United States Strategic Bombing Survey, that once they became available to him, he liked to use half-Jews as foremen to supervise this work "because of their higher intelligence."168

Gerhard Bernstein survived the war and the camp and eventually returned, for a time, to his family in Hamburg. How much he had been damaged psychologically and physically is impossible to determine. Pressure from the Nazis had not been enough to convince his wife to abandon and divorce him before the war, but their marriage did not last long after it. He died in Hamburg at the relatively young age of 62 .

Unlike his relatives, Gerhard Bernstein was interned in the Reich, not sent to one of the camps in the east, because, unlike them, he had married a German before the rules that limited such marriages had come into effect. Persons like him with one or two "fully Jewish grandparents" "in the racial sense" were considered "Jewish Mischling." 169 The Mischlinge occupied a kind of twilight zone in the racial categorizations introduced by the Nazis. They retained their civic status as Germans, but only weakly.

The classification of a Mischling changed if he voluntarily associated himself with the Jewish community. Such a person was reclassified as a "Geltungsjude," or a "deemed" Jew. A person deemed to be a Jew was treated as a Jew for the purposes of each of the discriminatory statutes and orders issued by the Nazis. Two of Gerhard's siblings, his sister Erna and his youngest brother Herbert, had associated themselves with the Jewish community by marrying Jews, and thus had been deemed Jews. Herbert's uncle Herbert had managed to get out of Germany and emigrate to the United States, while such emigration was still possible. Erna and her husband did not get out in time.

Their different respective classifications as Mischling and deemed Jew gave these two siblings, Gerhard and Erna Bernstein, different statuses under German law. As a Mischling, Gerhard retained his German citizenship. Erna, a Geltungsjude, did not. Erna

167. Id. It appears that those who were used after the catastrophic raids in July and August, 1943 were all prisoners of war. Beginning in 1944, "Halbjuden" and German prisoners were also employed in this work. HAMBURG FIELD REPORT, supra note 12, at 61.

168. HAMBURG FIELD REPORT, supra note 12, at 61.

169. Bernstein, Reflections, supra note 4, at 16. 
was subject to deportation to the east. Gerhard, for the time being at least, was not. In a State as profoundly lawless as Nazi Germany, there was every reason to believe that the rules might change. In a state as profoundly lawless as Nazi Germany, there was some protection for those who retained their citizenship until the rules did change, but as the conditions in Neuengamme gave eloquent testimony, not much.

\section{KLEINALARM, FLIEGERALARM AND HOCHBUNKERS}

There were more than one hundred and twenty-five Allied attacks on Hamburg from the air between the beginning of the war and the evening of July 24, 1943. "The raids extended from nuisance attacks to keep the population jittery, to 'heavy bombings.", ${ }^{170}$ The government developed an elaborate system of air raid warnings to enable the population to take shelter before the bombs began to fall. Observer stations far from Hamburg picked up evidence of enemy aircraft and began tracking them. Once it appeared that they might be heading toward Hamburg, various emergency personnel in the city were contacted and told to prepare for an attack. When the threat seemed likely to be directed at Hamburg, a Kleinalarm ${ }^{171}$ sounded from the sirens situated through the city, putting the public on notice that it should prepare to take cover. This alarm was merely a warning, and intended to put the population on a heightened state of alert. It did not, however, require any specific action. These alarms would have been a fact of life for Herbert from the time he was eleven until he was thirteen. Over the course of the entire war, such alarms sounded in Hamburg on average once every two or three days. ${ }^{172}$ Most of the time, they proved to be "false alarms." 173 The planes changed course or flew past Hamburg on their way to bomb Kiel or Lübeck or some other place. If the number of planes was large and

170. CAIDIN, supra note 12, at 23. The last heavy raid prior to July 1943 was in July 1942. Calculations of the number of attacks vary from 127 to 137 . They resulted in the deaths of 1,194 persons. See Hamburg im Krieg [Hamburg during the War], supra note 113.

171. The term means small alarm. It was also referred to as a "Vorwarnung" or early warning. HAMBURG FIELD REPORT, supra note 12, at 7-10.

172. Between the first attack in May, 1940 and the surrender of the city in May, 1945, the Hamburg civil defense authorities ordered the sounding of seven hundred and seventy-eight warnings or "Kleinalarm", and seven hundred and eight "Fliegeralarm." See Flakschutz für Hamburg im 2. Welkrieg [Anti-Aircraft Defense for Hamburg in the Second World War], at http://www.bunkerforschung.de/flakhamburg (last visited Oct. 4, 2002).

173. In about $70 \%$ of the cases in which an alarm was sounded, there was not an actual attack on the city. See id. 
closing in on Hamburg, the warning changed to a Fliegeralarm - fifteen rapid, four-second wails of the sirens. This alarm required everyone to take shelter, and the rules were enforced by block wardens and police. Regulations issued from Berlin mandated that this alarm not sound until the attacking planes were only ten minutes or sixty miles away from the city. Major General Alwin Wolz, the person responsible for the air raid warning system in Hamburg, soon reached the conclusion that those regulations were unrealistic. They did not give the public enough time to get out of their homes and into the shelters. As a result, he exercised a discretion that had not been given to him to sound the alarm when the planes were still twenty minutes away. ${ }^{174}$

The Nazis had started serious preparations to defend against air attack in 1935, and from 1937 all new buildings were required to have air raid shelters. ${ }^{175}$ There was, in addition, a major program to build shelters to protect those living in older buildings. These efforts were not sufficient, however, to meet the entire needs of this rapidly growing city. Whatever the regulations might require, there were not enough shelters to accommodate everyone. How many could be accommodated is a matter of some dispute. The answer depends in part on assumptions about how many more people actually crowded into the shelters than they were supposed to hold, and on definitions of what constituted a shelter. ${ }^{176}$ People took refuge in all sorts of places ranging from simple cellars in private homes, to spaces in basements of public buildings, to a variety of specially built air raid shelters. These specially constructed shelters were also of many different types. Some were underground shelters. Some were small above ground structures that looked like pillboxes. The most prized were massive above ground structures, known as Hochbunkers, many of which can still be seen in Hamburg today. ${ }^{177}$

174. See HAMBURG Field RePORT, supra note 12, at 7-10. The American report incorrectly spells his name "Woltz." Wolz would later defy Berlin again, and save Hamburg needless suffering, by surrendering the city to the British in violation of specific orders that he defend it. Hamburg im Krieg, supra note 113. Fliegeralarm translates into English as "air-raid warning."

175. Id.

176. According to the United States Strategic Bombing Survey Report the shelters in the city were able to shelter a third of the population at their rated capacities, but they were often crowded well above those ratings and may have sheltered closer to sixty per cent. HAMBURG FIELD REPORT, supra note 12, at 138-39. It is not clear what those unable to crowd in did when one of the mandatory Fliegeralarm sounded.

177. The Hamburg Museum gives the number of Hochbunkers as 108, and calculates that they were capable of sheltering about $10 \%$ of the population of the city. Hamburg im Krieg, supra note 113. The United States Strategic Bombing Survey counted, depending on definition, 
It might seem obvious that the safest place to be in the face of the onslaught of allied bombers would have been underground. What Herbert learned was that the obvious was not necessarily right. In the air attacks on Hamburg, the greatest danger, and by far the largest number of deaths, was not from explosions, but fire. In these fires, air was sucked out of the underground bunkers suffocating those shelter seekers who survived the initial blast. The Hochbunkers, above ground, thick walled, heavily reinforced structures, on the other hand, proved relatively impervious both to the destruction that rained from the skies, and the conflagrations that followed. ${ }^{178}$ It was Herbert's responsibility to work out the quickest route to the Hochbunker nearest to whatever apartment or remnant of an apartment he and his family were living in at the time, so that they could get there in time and would not be forced into one of the subterranean facilities by the police and block wardens. The Bernsteins, like most of the residents of the city, kept a packed case by the door to take with them to the bunker, so that they could there quickly, and so that they would have something in the event that the bombs struck their home.

The Hochbunkers proved an adequate protection for Herbert and his mother against the immediate loss of life and limb. But after they emerged from each successive bombing raid, there was less and less of a city to return to. The pace of bombing raids may have decreased after 1940, but the raids that occurred had a quite literal impact on the lives of the Bernsteins. The apartment that Herbert shared with his mother was destroyed in one of the early bombing raids, and the two of them were forced to find someone, who still had an apartment, to move in with. Then that apartment was destroyed in another raid, and both families had to find other friends with intact apartments. It was becoming an increasingly difficult task with each successive raid. As Herbert recalled the experience, their friends and neighbors were amazingly generous about taking them in. The repeated bombings did not cause the citizens of Hamburg to turn on each other. Herbert could not recall instances of apartments being

between seven and twenty-three more than that. HAMBURG FIELD REPORT, supra note 12, at 138-39.

178. In fact, they have proven difficult to remove in peacetime. For an account of the elaborate efforts of the demolition firm Georg Werner GmbH to destroy a World War II Hochbunker in Hamburg, see generally Spreng-und abbruchunternehmen, George Werner GMBH at http://www.b-i-m.de/Berichte/B06/B06z0697.htm (last visited Jan. 9, 2003). That particular air raid shelter was approximately sixty feet high. The walls and roof were made of steel reinforced concrete. The roof was more than four and half feet thick and the walls were more than three and a half feet thick. 
robbed during the raids, or even of anyone talking about the possibility.

Part of the answer to this one happy element in an otherwise seemingly unrelentingly depressing picture of life in Hamburg during the war is the obvious one. Nazi Germany was a police state. The authorities assumed the power to place people who needed shelter in the homes and apartments of those whom they determined to have extra space. It would have been an act of enlightened self-interest for the people of Hamburg to take in persons that they knew and liked, rather than wait to have someone unknown thrust on them. In addition, the authorities imposed elaborate regulatory schemes that made looting in the wake of the raids substantially more difficult. If someone salvaged property-moveable goods, food, or building materials - from a damaged building, that person was not permitted to take it away, even it belonged to him. He was permitted only to bring it out into the streets or to a nearby open area. The property was then transported to one of twenty-two depots set up around the city by the social welfare department, where it was catalogued. Only then was it turned over to a person who claimed it and could prove that it belonged to him. The process, which was bureaucratic and cumbersome, was supposed to limit looting. Apparently it did. ${ }^{179}$

The Report of the United States Strategic Bombing Survey suggests that there was another reason as well. The German national government had created an insurance scheme to compensate victims of enemy attacks for personal and property damage that they suffered, and for the profits that they lost. ${ }^{180}$ The compensation program was initially created by a decree dated November 10, 1940 . Additional decrees added various refinements over the course of the war, but the basic structure remained intact. Surprisingly, the system seems to have functioned effectively until close to the end of the war, even in the wake of the most devastating attacks. The bulk of claims submitted following the firestorms in Hamburg caused by the July/August 1943 attacks, which lead to the evacuation of half of the population, were reportedly cleared within sixty days. Those submitted after the several hundred smaller raids were processed substantially more quickly. ${ }^{181}$

179. HAMBURG FIELD REPORT, supra note 12, at 138-39.

180. Id. at 64-66, 74-79.

181. Id. at 76 . 
The physical injury and disability part of the compensation system was based on a government-sponsored, compulsory insurance system, under the terms of which all employed persons had a percentage of their pay deducted. It was administered at the lowest level by the existing office for the care of widows and orphans, but was backed up by national welfare office under the authority of the labor ministry. ${ }^{182}$ A German ${ }^{183}$ who was injured as the result of enemy action was entitled to payment for his medical care, and, if disabled from working, to a pension as well. Persons who had not paid into the plan, because they were not working, were treated the same as if they had. ${ }^{184}$

Those with injuries to property made their claims to different authorities, depending on whether their losses were more or less than 100,000 RM. A person who claimed damage to household goods was entitled to an immediate payment of $500 \mathrm{RM}$, and given an opportunity to prove actual losses if they were higher, and a streamlined procedure was set up for the settlement of such claims. ${ }^{185}$

The compensation scheme did not attempt to cover all losses. There were strict limits placed on the amounts paid to persons who could no longer work. ${ }^{186}$ Business losses, which were handled by a different authority-were subject to substantially greater restrictions. ${ }^{187}$ Those whose businesses had been destroyed and could not be repaired were compensated only if they intended to start a new business that was deemed to be desirable for the economy. Ship owners were not compensated until after they had actually made the expenditures to replace their ships. ${ }^{188}$ But if the compensation system did not cover all loses, it did provide a significant level of risk spreading, and meant that those most immediately affected by the bombing were not rendered totally destitute. It may have been an important factor in helping to maintain a measure of social peace under exceptionally difficult circumstances. $^{189}$

182. Id. at $74-75$.

183. A non-German could under special circumstances make a claim under the system, but had first to get the permission of the Ministry of the Interior. Id. at 76.

184. Id. at 75 .

185. Id. at 77

186. Id. at $75-76$.

187. Total compensation paid out under the business insurance scheme was only about $10 \%$ of total estimated losses. Payments by the Hamburg office totalled 2,380,256,924 RM on estimated total damages in Hamburg of 23,050,000,000 RM. Id. at 78-79.

188. Id. at 78

189. Before I began this paper, it had always struck me as curious that someone who had been through the sorts of experience that Herbert Bernstein had been through would choose to 


\section{DIE KATASTROPHE}

Sir Arthur Harris is supposed to have looked out on the fires burning in London after one of the German attacks on that city during the Battle of Britain and said: "Well, they are sowing the wind.", When he took over Bomber Command in February 1942, he began putting into place a plan that would insure that the people of Hamburg would reap what the Luftwaffe had sown. The attack that he planned, and put into execution in late July and early August, produced more destruction and greater loss of life than any previous air attack in history. ${ }^{191}$ The level and intensity of the destruction are difficult to comprehend. ${ }^{192}$ Once again, things were to happen to Herbert, because of an identity attributed to him, and over which he had no control. He was an enemy of the British Empire, and the wrath of that Empire, quite literally, came crashing down on his head. ${ }^{193}$

start his career studying insurance law. It seemed to me that in the wake of the social catastrophes that he had witnessed, insurance would seem like a vaguely pathetic response. In fact, his experiences may have led him to the opposite conclusion. The insurance system as it operated in Hamburg may have been essential to preventing a terrible situation from devolving into complete social chaos. Then again, it may have had nothing to do with his later decision. Hamburg has an important insurance industry, and Herbert may well only have been looking forward to career opportunities.

190. CAIDIN, supra note 12 , at 7.

191. There are numerous studies of the attacks, known as Die Katastrophe in Hamburg, and code-named Operation Gomorrah by British Bomber Command. See, e.g., Gordon Musgrove, Operation Gomorrah, THE HAMburg Firestorm RaIds 162 (1981) (concentrating on technical matters surrounding the operation and the firestorm); CAIDIN, supra note 12 (providing a British perspective on the human consequences of the attacks); MIDDLEBROOK, supra note 139 (describing the operation of these attacks in an easily accessible, readable manner).

192. President Roosevelt established the United States Strategic Bombing Survey on November 3, 1944 in hopes of better understanding the effect of strategic bombing, and of the military and civil defenses to it. The survey done of Hamburg has a repetitively chilling quality to it. The investigators found that the defenses of the city were well organized, and the personnel well trained. The warning systems were well conceived, and the emergency services well organized and well staffed. The Report found that, in general, each of the relevant services had responded effectively to Allied air attacks. At the end of each of the sections, there is then a qualification except in July/August, 1943. In the raids that took place during the ten days between July 24 and August 3,1943, the organization, training, and planning of each of the emergency services were overwhelmed. The unstated conclusion of the report was clear. An attack of such proportions could not be prepared for and would, if it came, result in terrible destruction. HAMBURG FIELD REPORT, supra note 12.

193. None of the account of Operation Gomorrah comes directly from Herbert. Although I asked him about it several times, he always deflected the discussion in another direction. He treated me to several learned monologues on the law related to the bombing of civilians, but, while he was willing to talk with me about his experiences of the smaller raids, he never talked to me about those ten days. 
The first attack began shortly before midnight on July 24, 1943. By the time it finished two and one half-hours later, in the early morning hours of July 25, seven hundred and forty planes had dropped 2,396 tons of bombs and incendiary devices. ${ }^{194}$ The bombs shattered windows, blew in doors, and insured that fire crews had to remain in the shelters. The incendiaries then set the exposed buildings on fire. ${ }^{195}$ It proved a remarkably effective tactic. At one point that night, fifty-one miles of building frontage were burning. ${ }^{196}$ Twelve hours after the bombers flew back to their bases in England, a second smaller attack sent the dazed inhabitants of Hamburg scrambling back into their shelters. After two days of respite, a second major attack began at twenty minutes before midnight on July 27. This time seven hundred and thirty-nine planes dropped 2,417 tons of bombs and incendiaries on the city. ${ }^{197}$ At one point, there were an estimated 7,000 buildings, 129 miles of building frontage, on fire. ${ }^{198}$ After just one night of respite, there was a third major attack on July 29, with 726 planes dropping 2,382 tons of explosives and incendiaries on the city. ${ }^{199}$ The third major attack set 98 miles of building frontage on fire. ${ }^{200}$ The raids continued through August 3. Over the course of the ten days, more than a hundred thousand bombs, and three million incendiary devices fell on Hamburg, reducing 6,000 acres to ash and ruin. $^{201}$ The devastation was so complete that the later attacks began to run into the law of diminishing returns. In many parts of the city, they failed to produce any new fires, because there was nothing left to burn. ${ }^{202}$

The worst of the attacks, that of July 27-28, produced a new phenomenon, a thermal firestorm of almost unimaginable horror. On what had been a hot, still evening, the firestorm created powerful winds that caused many little fires to become a single huge conflagration, which in turn caused those winds rushing in to feed the fire to reach hurricane force. ${ }^{203}$ The winds tore trees apart and made it im-

194. CAIDIN, supra note 12, at 63-64.

195. MUSGROVE, supra note 191, at 109.

196. HAMBURG FIELD REPORT, supra note 12, at 31.

197. CAIDIN, supra note 12, at 63-64.

198. HAMBURG FIELD REPORT, supra note 12, at 31.

199. CAIDIN, supra note 12, at 63-64.

200. HAMBURG FIELD REPORT, supra note 12, at 31.

201. CAIDIN, supra note 12, at 9.

202. MUSGROVE, supra note 191 , at 146.

203. Id. at 110 . 
possible for fire crews to get near the fire. ${ }^{204}$ Temperatures reached 1,400 degrees Fahrenheit, reducing the bricks in some of the shelters, where the inhabitants of Hamburg had attempted to take refuge, to ash. ${ }^{205}$ Burning gases were carried up almost three miles into the night sky, ${ }^{206}$ and the fire produced a smoke cloud that eventually rose to 30,000 feet. ${ }^{207}$ A member of one of the Allied bomber crews reported that he could see Hamburg burning from 90 miles away. ${ }^{208}$

This extraordinary and unprecedented phenomenon would become the subject of many scientific studies. ${ }^{209}$ On the night of July 27 and 28, it was an incomprehensible devastation. The Hamburg authorities officially designated the fire area a "Dead Zone." The authorities estimated that 31,000 people had been killed, but it was impossible to know with any certainty. ${ }^{210}$ Many bodies had been reduced to ashes, and much of the area was so hot that no one could go into it for days. ${ }^{211}$ When rescue crews finally went in and opened the doors of bomb shelters looking for survivors or bodies, the rush of oxygen into these still superheated spaces caused whatever was flammable in there, including the bodies, to burst into flame.

Herbert and his mother fortunately were not in the Dead Zone. Their Hochbunker was one of the ones that did survive the bombing. ${ }^{212}$ But when they emerged after the all clear, they discovered that they had no home to return to. He and his mother had survived, but most of his native city had not. Herbert Bernstein was thirteen and a half years old.

In the wake of the devastation visited by Operation Gomorrah, the Gauleiter for Hamburg, Karl Kaufmann, repeatedly requested that Hitler come to the city to raise the spirits of the people. ${ }^{213}$ When

204. HAMBURG Field REPORT, supra note 12, at 32.

205. CAIDIN, supra note 12, at 93.

206. Id.

207. MUSGROVE, supra note 191, at 109.

208. CAIDIN, supra note 12, at 93.

209. MUSGROVE, supra note 191, at 102.

210. Id. at $115-16,166$. Some of the authorities actually thought that the number was much higher than that. The Fire Department told the United States Strategic Bombing Survey investigators that they believed that 55,000 had died and that they had recovered 45,000 bodies. HAMBURG FIELD REPORT, supra note 12, at 32. The Hamburg Museum now estimates that the total number of deaths was 35,000 , significantly less than that thought at the time. Hamburg im Krieg, supra note 113.

211. MUSGROVE, supra note 191, at 102.

212. Other structures did not perform as well. Two thirds of those who had taken shelter in the "splinter proof shelter" on Eichenstrasse died in it. Id. at xxix.

213. KeRSHAW, NeMESIS, supra note 109, at 598. Albert Speer also added his voice to that 
Hitler would not come to Hamburg, Kaufmann organized a delegation of emergency services workers who had done particularly meritorious service during the attacks, and sent them to Berlin to see the Führer. Hitler refused to meet with them. ${ }^{214}$ Joseph Goebbels, noting that Hitler had not spoken to the public in more than three months, pleaded with him to address the German people by radio "even for only a quarter of an hour." 15 Hitler stated that the situation was "as unsuitable as could be imagined," and refused to do it. ${ }^{216}$ Instead, Hermann Göring was convinced to go into Hamburg. He arrived on August 6, but left the same day. ${ }^{217}$ Göring told his aides that he found the experience depressing, and that he wanted to get away from Hamburg. ${ }^{218}$

\section{LIVING IN A PIG STY}

Before the raids, Hamburg had 122,323 houses and 450,000 apartments, most of which were contained in large buildings to the east of the River Alster. After the attacks, a third of the houses and fifty-six percent of the apartments were either completely destroyed or damaged beyond repair. ${ }^{219}$ It no longer made sense to move in with someone whose house or apartment had not been destroyed. There were not enough houses or apartments left. The only water supply in the city came from water carts. There was no tap water, and would not be any for three weeks. Even then, there were so many breaks in the water mains that pressure could not be maintained to raise the water above street level. Not until November was water service restored. ${ }^{220}$ There was no electricity and no gas in the city. The sewer system was badly damaged and trash was not picked up for weeks. ${ }^{221}$

Like Göring, most people wanted to leave Hamburg, but because they found the prospect of staying to be terrifying, not depressing. ${ }^{222}$ However, leaving was not so easy for them. The roads were filled with rubble and many were impassible to vehicles. Public transporta-

of Gauleiter Kaufmann, with similar lack of effect. MIDDLEBROOK, supra note 139, at 357-58.

214. KERSHAW, NEMESIS, supra note 109, at 598.

215. Id.

216. Id.

217. MIDDLEBROOK, supra note 139, at 357.

218. Id. at 358.

219. MusGROVE, supra note 191, at 162.

220. Id. at $162-63$.

221. Id. at 164.

222. HAMBURG FIELD REPORT, supra note 12, at 157. 
tion had all but ceased, and what remained was not allowed to cross the part of the city designated a "Dead Zone." Rail stations and tracks were destroyed, along with a quarter of the rolling stock of the U-bahn. ${ }^{223}$ Some people gathered in parks and race tracks to await such transportation as the authorities could organize. Others decided not to wait for anyone, and took every conceivable form of transportation, or simply walked, in an effort to get away from the city. The surrounding communities were soon overrun with these refugees, as were the camps hastily set up to receive them. Late arrivals were forced to push further into the countryside away from Hamburg. ${ }^{224}$

In the chaos, governmental controls designed to keep track of who was going where broke down, so there is no entirely satisfactory estimate of the total number of refugees. ${ }^{225}$ The situation was further complicated by the fact that some people started to try to move back into the city, while others were still trying to get out. What is certain is the scale of the exodus. In the days following the final raid on August 2 and 3 1943, between 800,000 and 1,000,000 people, about half the population of this second largest city in the Reich, left their homes to seek shelter somewhere else. ${ }^{226}$ Only those associated with strategic industries or the government remained in the city. Those able to go to friends and relatives did so. Those unable to find such places to go were relocated, some to the countryside around the city, others deep into the interior of the Reich. ${ }^{227}$

Many of those who fled the bombing tried to return, once they had discovered what was available to them outside of Hamburg. The authorities, struggling to make Hamburg functional again, did what they could do to prevent them from doing so. Initially, the return of women and children was banned, and later all schools in the city were ordered to be shut down in an effort to discourage their return. These efforts were only partially successful. About fifteen percent of those who had fled returned to the city by the end of August. ${ }^{228}$ Most of the rest, like Herbert and his mother, did not return until late 1944, or until after the war.

223. MUSGROVE, supra note 191, at 164.

224. Id. at 162-65; HAMBURG FIELD REPORT, supra note 12, at 157-58.

225. HAMBURG FIELD REPORT, supra note 12, at 158.

226. The number who fled constituted about two thirds of the civilian population. E.g., MidDLEBROOK, supra note 139, at 358; HAMBURG FIELD REPORT, supra note 12, at 157.

227. HAMBURG FIELD REPORT, supra note 12, at 157-58. Those evacuated to nearby areas were well received by the local population, but those sent to Bavaria frequently encountered hostility. MIDDLEBROOK, supra note 139, at 358.

228. HAMBURG FIELD REPORT, supra note 12, at 158. 
Fortunately, Herbert and his mother knew a family that had a farm relatively near to the city. That family had no room in their house or their barn, which had long since been taken over by other homeless families. They did, however, have a pig sty. The Bernsteins, mother and son, gratefully accepted the offer. For those who did not live through that time in Germany, this offer conjures up images of Bruegel-like chaos, with animals and people living together in some sort of riot of life. The reality was far less colorful. With the shortages attendant on the war, the pigs had been gone for years. What was left was a cold, unheated, spare space that provided little privacy, but offered shelter from the North German winter. It was not much, but it was better than the alternatives.

The Bernsteins remained on the farm, in the pig sty, through at the least the spring of $1944 .^{229}$ Somehow, in ways that I have never understood, Herbert managed to continue his education. He was fortunate that after the authorities closed the schools in the center of the city, they relocated them out the fringes and reopened them in October, $1943 .^{230}$ One of these schools was apparently close enough to the farm for Herbert to get to it. It might seem, nonetheless, that even if one could manage to get to a school that was not bombed out or closed by the authorities and find a teacher who had not been conscripted or interned, that it would have been next to impossible, under the circumstances, to motivate oneself to study the Latin texts that were such a significant part of the curriculum. Herbert told me that for him the disruption had the opposite effect. He said there was something comforting about things that seemed timeless in a time of such impermanence, things that were part of a common Western tradition at the time when the West was literally tearing itself apart.

Herbert was not, of course, left alone to study Latin, even in the pig sty. While he was there, he turned fourteen, and the Nazis had other plans for him.

\section{JOINING THE HITLER YOUTH}

When he turned 14, Herbert was required, along with all other German boys of his age to join the Hitler Youth, and became Hitlerjunge Bernstein. Herbert, on more than one occasion, noted the

229. See Neil Vidmar, Remarks at the Memorial Service for Herbert Bernstein, April 25, 2001, http://law.duke.edu/fac/bernstein/vidmar.html (placing Herbert Bernstein at the farm on Hitler's Birthday in 1944).

230. HAMBURG FIELD REPORT, supra note 12 , at 158. 
irony of this title. The elaborate racial categorizations of the Nazis that had led them to deport and then murder many of his relatives, and arrest and intern his father in a concentration camp, caused them to mandate that he do his "honorary service for the German people." Had the racial lines been drawn in a different place, he noted, he too might have been sent to the east, rather than sent off in his Nazi uniform to prepare for service to the Reich. Herbert detested the association of his name with Hitler's. He was quite sure that, if Hitler had known, he too would have been deeply offended to have his name associated with Herbert's.

If the symbolism of participation in the Hitler Youth was jarring and distressing, his actual participation ended up being a fairly pedestrian experience. Herbert, once again, was forced to participate in a regimen of physical exercise and gymnastic training, in which once again he distinguished himself by his lack of aptitude. Since part of the purpose of the Hitler Youth experience was to train young German boys for their future roles in the defense of the Fatherland, he also had to learn a variety of military skills, such as map reading. It turned out that he was as good at map reading as he was bad at gymnastics. He was so good, in fact, that he was selected to receive the award in map reading at a ceremony honoring those in the Hitler Youth who had achieved special distinction. The event presented a rare opportunity for his mother to bask in the reflected glory of her son's achievement. When the day came, it was not to be. The Party official, who had been brought in to give an inspirational speech and hand out the awards, discovered to his horror the intolerable juxtaposition of a Jewish name next to a Hitler Youth achievement award. In the middle of the ceremony, he demanded that the map-reading award be given to someone more suitable. Herbert was German enough to be able to do "honorary service for the German people," but not German enough to receive an award for excellence in map reading. Protection of German Blood and German Honor required constant vigilance and individual initiative.

The discrimination suffered by Herbert at the Hitler Youth award ceremony was probably the product of the pettiness of a particular Party official, rather than official policy. There was nothing in the regulations that required it. It mirrored, however, the sorts of distinctions that the Nazis applied to adults in the military, as they tried to work out the logic of their racist policies against the backdrop of wartime needs. In 1934, the Nazis had forced Jews out of the military 
in an extension of their program of Aryanizing the civil service. ${ }^{231}$ The following year, they reintroduced conscription in March 1935, ${ }^{232}$ and, as they would later with the Hitler Youth, subjected Mischlinge to it. ${ }^{233}$ The Mischlinge were not initially permitted to be promoted to higher rank. ${ }^{234}$ But the problems of racial categorization, and the difficulties of adapting it to those who did not easily fit into one or another grouping, led to further elaboration of these rules in 1940. Recognizing the usefulness of at least some Mischlinge, the Nazis changed the rules to permit those with one only one fully Jewish grandparent to be promoted "in exceptional circumstances." Those with two fully Jewish grandparents, on the other hand, were not to be used, no matter how exceptional the circumstances. They were discharged from the armed forces. ${ }^{235}$

Herbert never had to deal personally with the working out of racial categories in the context of service in the military. He was too young to be conscripted into the Wehrmacht. He was not, however, too young to avoid being conscripted into the Volkssturm, or peoples' militia. This organization probably originated as the idea of Martin Bormann. ${ }^{236}$ It was in equal parts the product of the increasingly desperate military situation of the Third Reich, and an important expression of Nazi ideology. ${ }^{237}$ In August, September and October 1944, the Wehrmacht suffered casualties of $1,189,000 .^{238}$ There were virtually no reserves of manpower available to replace those losses. More than twenty per cent of the German workforce, by this point, consisted of

231. Bernstein, Reflections, supra note 4, at 8. Those "not of Aryan descent" included all persons with at least one Jewish grandparent. See First Regulation, supra note 71, v.11.4.1933 (RGB1.I S. 195) available at $\mathrm{http}: / / \mathrm{www} . s a l v a t o r . n e t / \mathrm{salmat} / \mathrm{pw} / \mathrm{pw} 1 / \mathrm{macht} / \mathrm{beamte} . \mathrm{htm}$. Certain exceptions were made for, among others, persons who had served at the front during the First World War. Id.

232. Wehrgesetz [Military Law], v.21.5.1935, (RGB1.I S. 609). For an account of the reintroduction of military conscription, see KERSHAW, HUBRIS, supra note 1, at 550-52.

233. Bernstein, Reflections, supra note 4, at 18.

234. Wehrgesetz, supra note 232, §15-3, (explaining that "Arische Abstammung" [Aryan descent], precluded those not of Aryan descent from becoming "superiors").

235. Id.

236. Alastair Noble, The People's Levy: The Volkssturm and Popular Mobilization in Eastern Germany, 1944-45, 24 J. STRATEGIC STUD. 165 (2001); see also 11 THE TRIAL OF GeRMAN MAJOR WAR CRIMINALS 597-598, available at http://nizkor.org/hweb/imt/tgmwc/tgmwc-11-10007.shmtl (presenting testimony of Dr. Bergold (counsel for Bormann) concerning the Volkssturm, Nuremberg, April 5, 1946, at 58).

237. Daniel K. Yelton, "Ein Volk Steht Auf": The German Volkssturm and Nazi Strategy, 1944-45, J. MiL. HIST. (Oct. 2000), at 1061, 1063-64.

238. KERSHAW, NEMESIS, supra note 109 , at 713. 
foreign conscript labor. ${ }^{239}$ Whatever replacements were going to be found would have to come from the old and the young. No one else was left. ${ }^{240}$ But if born of desperation, the Volkssturm also represented a symbolic statement for the Nazi ideologues of the unity of the German people in the face of the enemy, of the "Party's belief in the "triumph of the will," "the overcoming of overwhelming obstacles through "sheer willpower.",241

Hitler created the Volkssturm by decree on September 25, 1944, subjecting all men between the ages of sixteen and sixty and capable of bearing arms to service in it. ${ }^{242}$ The Volkssturm was then formally launched by Heinrich Himmler on October 18, 1944, the $131^{\text {st }}$ anniversary of the defeat of Napoleon at the "Battle of the Peoples" and the liberation of German territory. ${ }^{243}$ Ill-equipped and worse trained, the Volkssturm proved to be largely ineffective as a fighting force. ${ }^{244}$ In the absence of alternatives, the Nazis continued nonetheless to call up more and more of younger and younger German boys. In February or March 1945, fifteen-year-old Herbert received notice that he had been conscripted into the Volkssturm as part of the preparations for the final defense of the Reich. It is remarkable in the chaos during the weeks before the final collapse of the Nazi regime that the government still functioned well enough to find him and get him the notice.

The usual procedure was to work through the existing structure of the Hitler Youth, and to conscript the members of each of the units together. If the conscript failed to show up at the appointed time, either by sending word that he was ill, or by simply not appearing, the authorities frequently were not up to the task of tracking down the shirkers. ${ }^{24}$ Apparently something of the sort happened with Herbert, and Hitlerjunge Bernstein avoided becoming Volkssturmer Bernstein. He successfully ignored the summons until it was too late to

239. Id.

240. No one else was left except the 187,000 men who were commandeered by Goebbels in 1944 to act as extras in the film Kohlberg, an epic depicting the defense of a Baltic town against Napoleon. Id. at 713 .

241. Id. at 713 .

242. The decree is available in translation in IV JEREMY NOAKES, NAZISM: THE GERMAN HOMEFRONT IN WORLD WAR II 643-644 (1998).

243. KERSHAW, NEMESIS, supra note 109, at 713.

244. See Order of the Fuehrer on Employment of the Volkssturm, January 28, 1945, available at http://www.geocities.com/pentagon/1084/fuehrer_directives.htm.

245. Interview with Dr. Bernd Michaels (recalling his personal experiences and recollections regarding the procedure of conscription into the Volkssturm during the war). 
participate in the inaptly named Endsieg, or final victory. Possibly for the first time in his life, he successfully avoided being forced to assume an identity that someone else wanted to thrust on him.

\section{DAS HUNGERWINTER}

The end of the war ended the threat of conscription and brought the release of his father from Neuengamme, but it hardly ended the hardships of his early life. Hamburg was one of the most heavily bombed of all German cities. By May 1945, half of its housing stock had been completely destroyed and only twenty per cent was undamaged. $^{246}$ The apartment where Herbert and his mother lived had some, but not all, of its exterior walls. Through all the bombings, the municipal authorities in Hamburg had done a heroic job of feeding, after a fashion, their population. The invading and later occupying British forces were not as motivated or equipped to take up the challenge. To make matters worse, the first winter after the war was unusually severe. ${ }^{247}$ The result was that those who had lived through the horrors of war in Hamburg remembered the first year after it as one of unusual hardship. ${ }^{248}$

Recovery and reconstruction were complicated by a sharp increase in the population of the city at the end of the war. Between May 1945 and December 1947, the population of Hamburg grew by 500,000 as refugees from the east, former Hamburg residents who had fled into the countryside, former soldiers, and groups of homeless persons poured into the shattered city. ${ }^{24}$ This influx dramatically worsened an already severe housing shortage. ${ }^{250}$ As late as 1948,

246. Die moderne Metropole [The Modern Metropolis], Museum für Hamburgische Geschichte [Hamburg Museum], at http://www.hamburgmuseum.de/d/htm_d/textversion/20jhd2-03.html (last visited Oct. 4, 2002).

247. Hungerwinter [Winter of Hunger], Museum für Hamburgische Geschichte [Hamburg Museum], at http://www.hamburgmuseum.de/d/htm_d/textversion/20jhd-2-01.html (last visited Oct. 4, 2002).

248. Id.

249. According to the Report of the United States Strategic Bombing Survey, the population of Hamburg at the beginning of the war was 1.7 million. In the wake of operation Gomorrah, it fell to approximately 800,000. Between August, 1943 and May, 1945, as many of those, like Herbert and his mother, who had fled returned to the city, the population grew again to approximately 1.1 million. HAMBURG FIELD REPORT, supra note 12, at 2. On the increase in population between May, 1945 and the end of 1947, see, Hungerwinter, supra note 247.

250. The housing shortage was then further worsened by the seizure of housing units, and the expulsion of their 40,000 tenants, for use by the occupying British forces. Von der besetzten Stadt zum Bundesland, Museum für Hamburgische Geschichte [Hamburg Museum], at http://www.hamburgmuseum.de/d/htm_d/textversion/20jhd-2-02.html (last visited Oct. 4, 2002). The British occupation of Hamburg did not end until 1956. 
about an eighth of the population were living in temporary housing, a significant percentage of them in Quonset huts made out of corrugated steel. ${ }^{251}$

The housing shortages were mirrored by equally severe shortages of food and heating fuels, leading to the development of an extensive black market. Those who had managed to make it through the war with goods that they could use for barter went into the surrounding countryside to try to pry loose food from those who were hoarding it. ${ }^{252}$ Herbert and his family had started the war with little, and ended it with considerably less. They, like many other residents of the city, had little to barter with, and so resorted to stealing what they could not buy. To get coal to heat their accommodations through that bitter winter of 1945-46, Herbert, along with many of his neighbors, robbed the slow moving Allied supply trains as they made their way through the city. ${ }^{253}$ Ironically their efforts were greatly aided by the fact that the trains had to move so slowly, because Allied bombing had heavily damaged the railbeds, which were no longer able to carry trains at speed. ${ }^{254}$

\section{A NEW ROAD}

Two years later, Herbert Bernstein began a much happier journey than the ones he had known to date. Having lived through all of the chaos of the Third Reich, the war and occupation, Herbert finally succeeded in finishing his training at the Gymnasium. He took the short trip north to Kiel to begin his studies in law at the ChristianAlbrechts-Universität zu Kiel. It might be possible to make something of the symbolism of this young man, whose entire life had been lived under lawless regimes, going to study law at an institution that was founded in the wake of an earlier devastating religious war, ${ }^{255}$ especially at one whose institutional motto is Pax Optima Rerum peace is the greatest good. ${ }^{256}$ The explanation for his choice was almost certainly far more prosaic. His resources and thus choices were

251. Hungerwinter, supra note 247.

252. Id.

253. This pervasive activity became so common that the people of Hamburg developed a special term, "Kohlenklau" - coal swiping, to describe it. See id.

254. According to Herbert, the Allied troops made little effort to interfere with him and his neighbors as they grabbed the coal off the trains.

255. The University was founded in the wake of and partly in response to the Thirty Years War. Geschichte der Universität [History of the University] http://www.unikiel.de/ueberblick/ geschichtedercau.html.

256. Id. 
very meager, and things in Hamburg were still very bad. The University there had re-opened shortly after the end of the war, but conditions were extremely difficult. The University of Hamburg admitted some 3,400 students in the winter of 1946 into an institution illequipped to deal with them. ${ }^{257}$ The University had been badly damaged in Operation Gomorrah, and at the end of the war, the main buildings were still unusable. The faculty had been drastically reduced in size through purges, ${ }^{258}$ retirements, and deaths; and most of those who remained had had their books and equipment destroyed during the war. ${ }^{259}$ The stepdaughter of the Rector of the University, who had returned to the city as a war correspondent, was powerfully struck by the pervasive grimness of the place. The student body, she noted, was a "conspicuously maimed group," forced to eat and study in unheated rooms, and to use up extraordinary amounts of energy seeking out the bare means of survival. ${ }^{260}$ By her estimate, no more than one in a hundred students had his own room to live in. ${ }^{261}$ If Herbert attended Kiel, he could live with his grandparents, the Franzes. It would not be a comfortable start to his academic life. He would have to make do during his first year at university sleeping on a bed in the corner of the kitchen in his grandparents' modest home. But then none of the beginnings in his life had been comfortable, and the conditions in Hamburg would almost certainly have been much worse. The motto was nice and poignant, but had little to do with the decision to travel north.

The situation at the University of Hamburg apparently improved enough during the year that Herbert spent at Kiel that he decided to return to his native city to continue his study of law. Things undoubtedly were still grim, but the Hamburg that he was returning to was beginning to transform itself from a burned out hulk of city into the dynamic international center that it had been and would become

257. There were approximately 7,000 applicants, many of whom reportedly tried to bribe the Rector into admitting them. See WOLFF-MönCKEBERG, supra note 8, at 165, 167.

258. The Nazi purges of the faculty were followed after the war by purges of Nazis by the Allies. These latter purges resulted in the dismissal of $30 \%$ of the faculty who remained at the University of Hamburg at the end of the war. Von der besetzten Stadt zum Bundesland [From an Occupied Country ot the Federal Republic], supra note 250.

259. See WOLFF-MÖNCKEBERG, supra note 8, at 167.

260. Ruth Evans had been raised in Hamburg, but then married a Welshman and spent the war in Great Britain. What makes her comments all the more striking is the fact that her base of comparison was the hardly luxurious conditions of post-war Welsh universities. Id. at 168.

261. Id. Given the "harsh circumstances of daily life," the examination results of the students were, she noted, "astonishingly high." 
again. $^{262}$ The currency reform instituted on June 20, 1948, which introduced the DM, had a dramatic and immediate impact on the economy. ${ }^{263}$ The University entered a promising phase of sustained growth. ${ }^{264}$ Herbert had survived, if only barely, a Hamburg boyhood, and could begin to look forward to a much more productive life as an adult citizen of Hamburg and of the world. The boy who had been expelled from the gymnastics classes because he was not Aryan enough, and who had been denied his map reading prize because of his name, would finally get the chance to forge his own identity.

\section{CONCLUSION}

When the Lord Chief Justice Edward Coke died in 1634, his widow uttered the wonderfully ambiguous sentiment: "We shall never see his like again, praises be to God." ${ }^{265}$ The undoubtedly unintended ambiguity of her comment delighted Herbert Bernstein, and he quoted it on more than one occasion in reference to one colleague or another who had managed to distinguish himself in ways that were similarly ambiguous. I suspect that Herbert's early experiences as a boy in Hamburg shaped the man I knew. I suspect that the effects of those years on him were profound, and had much to do with the extraordinary depth of decency and humanity of this unusual man. If I am right that his experiences were critical in shaping him, I know that all those who knew him are the richer for what he went through. He was proof of human resiliency. Given what he went through, I can

262. The University of Hamburg, despite the heroic efforts of its public relations department to prove otherwise, was founded immediately after the First World War. WOLFFMÖNCKEBERG, supra note 8, at 20. Cf. Die Geschichte der Universität Hamburg [The History of the University of Hamburg], University of Hamburg, at http://www.unihamburg.de/ PSV/PR/Presse/geschich.html (last modified Oct. 6, 2000). Despite the fact that Hamburg was not primarily an intellectual or academic center, the University quickly assembled a dynamic and distinguished faculty, including such world renowned scholars as Erwin Panofsky (art history), William Stern (psychology), Otto Stern (physical chemistry) and Ernst Cassirer (philosophy) during the Weimar Republic. All four of them left, along with many others, when the Nazis came to power. Short Introduction to the University of Hamburg, University of Hamburg, at http://www.uni-hamburg.de/Publikat/falt_e.html (last modified May 2001). It would take heroic efforts after a second twentieth century war to re-establish the glory of the early interwar period.

263. See Hungerwinter, supra note 247.

264. See Short Introduction to the University of Hamburg, supra note 262.

265. See SAmuel E. Thorne, EsSAys In English Legal History 224 (1985). Lord Coke was an extraordinary figure in English legal history, who, as Thorne notes, "has often been regarded as the protector and defender of the traditional rights of Englishmen." Id. at 231. Included among those "traditional" rights were ones that were entirely "his own invention." Id. He was also "an unpleasant, hard grasping, arrogant, and thoroughly difficult man." Id. at 224. 
only hope that there will never be another like him, because no one should ever experience a Hamburg boyhood like his. 